\title{
DISCLAIMER
}

This report was prepared as an account of work sponsored by an agency of the United States Government. Neither the United States Government nor any agency thereof, nor any of their employees, makes any warranty, express or implied, or assumes any legal liability or responsibility for the accuracy, completeness, or usefulness of any information, apparatus, product, or process disclosed, or represents that its use would not infringe privately owned rights. Reference herein to any specific commercial product, process, or service by trade name, trademark, manufacturer, or otherwise does not necessarily constitute or imply its endorsement, recommendation, or favoring by the United States Government or any agency thereof. The views and opinions of authors expressed herein do not necessarily state or reflect those of the United States Government or any agency thereof.

\section{Department of Energy Idaho Operations Office Evaluation of Feasibility Studies for Private Sector Treatment of Alpha and TRU Mixed Wastes}

Published May 1995 


\section{DISCLAIMER}

Portions of this document may be illegible in electronic image products. Images are produced from the best available original document. 


\begin{abstract}
The Idaho National Engineering Laboratory (INEL) is currently storing a large quantity of alpha contaminated mixed low level waste which will require treatment prior to disposal: The DOE Idaho Operations Office (DOE-ID) recognized that current knowledge and funding were insufficient to directly pursue services for the requisite treatment. Therefore, it was decided that private sector studies would be funded to clarify cost, regulatory, technology, and contractual issues associated with procuring treatment services. This report analyzes the three private sector studies procured and recommends a path forward for DOE in procuring retrieval, assay, characterization, and treatment services for INEL transuranic and alpha contaminated mixed low level waste. This report was prepared by a team of subject matter experts from the INEL referred to as the DOE-ID Evaluation Team.
\end{abstract}




\section{Table of Contents}

Evaluation of Feasibility Studies for Private Sector Treatment of

Alpha and TRU Mixed Waste

EXECUTIVE SUMMARY $\ldots \ldots \ldots \ldots \ldots \ldots \ldots \ldots \ldots \ldots \ldots \ldots \ldots \ldots$ ix

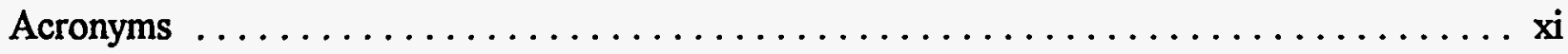

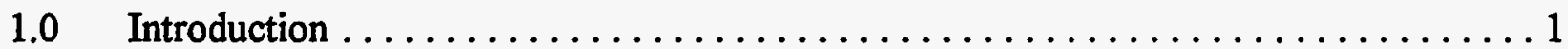

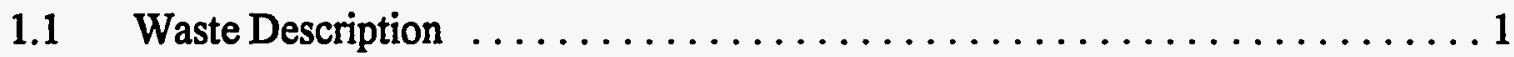

1.2 Regulatory Status/Environment, Safety and Health Risk $\ldots \ldots \ldots \ldots \ldots 2$

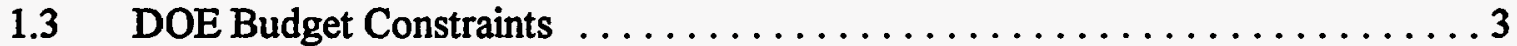

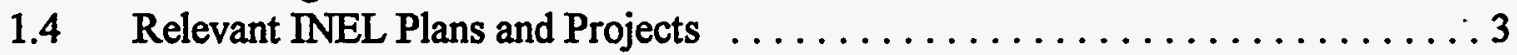

1.5 Feasibility Study Concept and Associated Request For Proposal (RFP) . . . . . 4

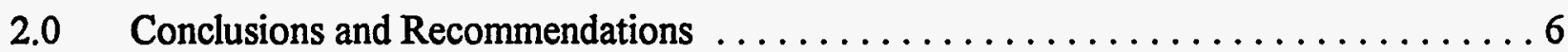

3.0 Summary of Private Sector Approaches and DOE Assessment of Approaches . . . . . . 7

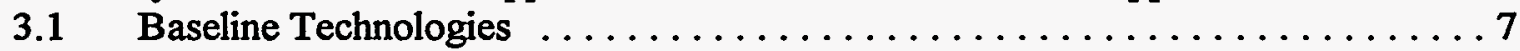

3.1.1 Treatment Technology Screening $\ldots \ldots \ldots \ldots \ldots \ldots \ldots \ldots \ldots$

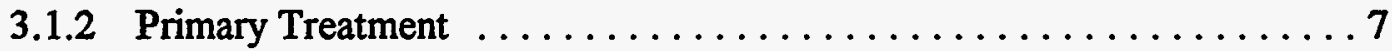

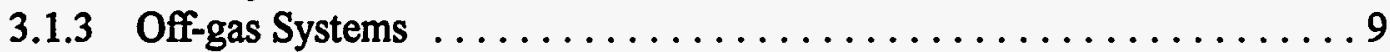

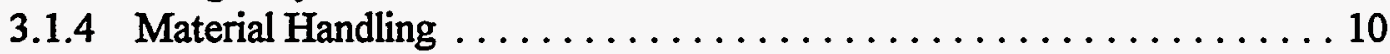

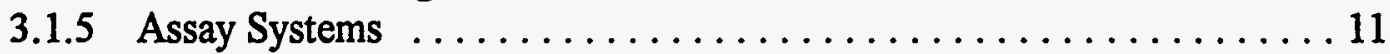

3.1.6 Radiological and Hazardous Material Control .............. 11

3.1.7 Criticality Control ........................... 13

3.2 Technology Development Plans and Requirements $\ldots \ldots \ldots \ldots \ldots \ldots \ldots$

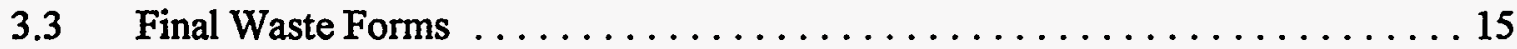

3.4 Volume Reduction ................................. 17

3.5 Treatment Facility/Services Waste Acceptance Criteria $\ldots \ldots \ldots \ldots \ldots 17$

3.6 Treatment Facility Location and Transportation Issues $\ldots \ldots \ldots \ldots \ldots \ldots 18$

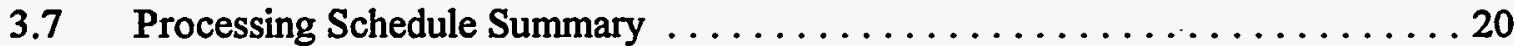

3.8 Retrieval . . . . . . . . . . . . . . . . . . . . . . . 21

3.9 INEL TRU Waste Program Impacts/Description of IWPF Base Case . . . . . 22

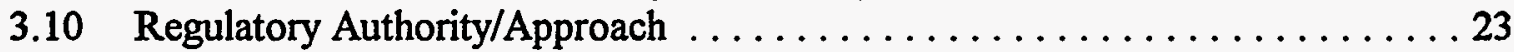

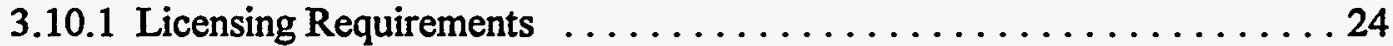

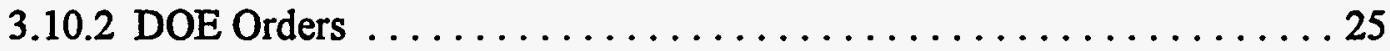

3.10.3 Occupational Safety and Health Administration (OSHA) Requirements . 26

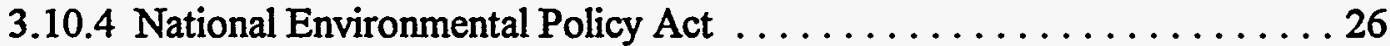

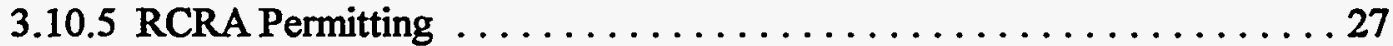

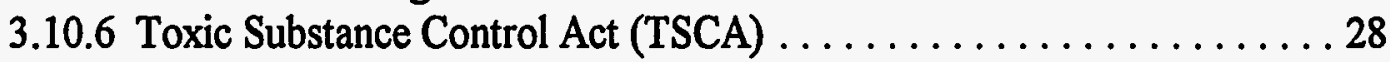




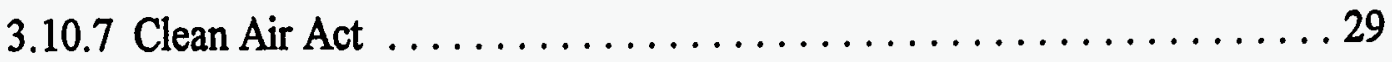

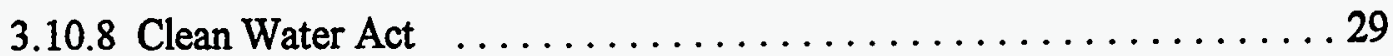

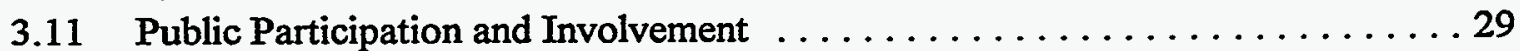

3.12 Contractual, Business and Financial Terms $\ldots \ldots \ldots \ldots \ldots \ldots \ldots \ldots \ldots \ldots \ldots$

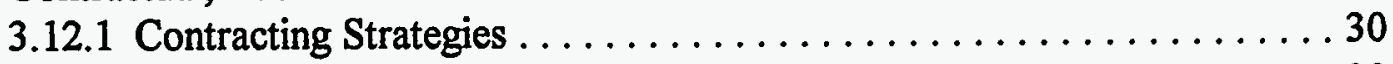

3.12.1.1 Pre-Construction Contracting Strategy .......... 30

3.12.1.2 Construction Contracting Strategy ..............31

3.12.1.3 Operations Cycle Contracting Strategy ........... 31

3.12.1.4 Decontamination and Decommissioning (D\&D) Contracting

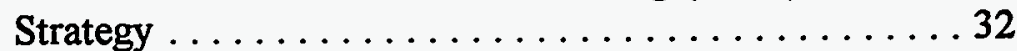

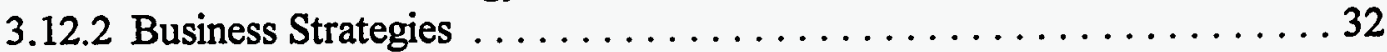

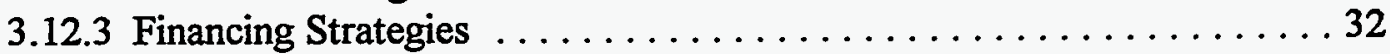

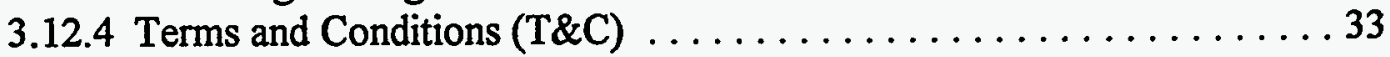

3.12.5 Private Sector Approach to Other Markets and Pricing Strategies . . . . 34

3.12.5.1 Other Markets - TRU Treatment .............. 34

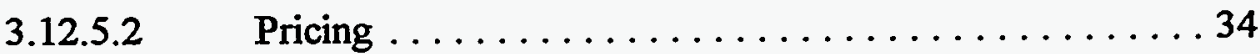

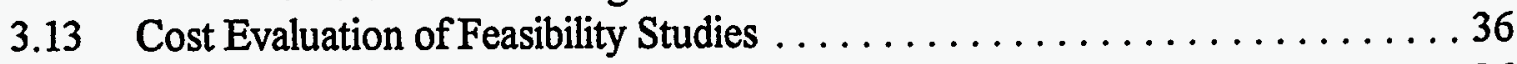

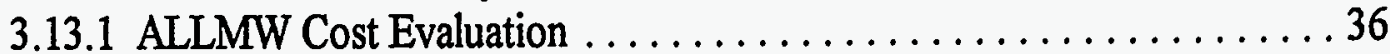

3.13.2 TRU Cost Evaluation .......................... 37

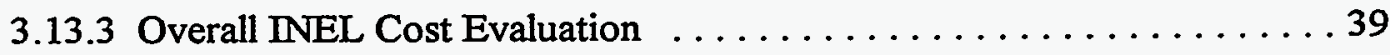

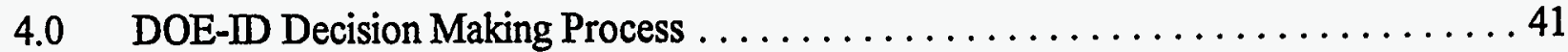

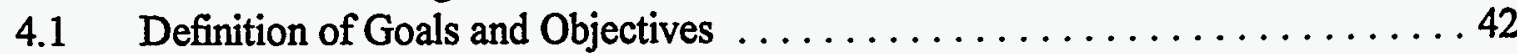

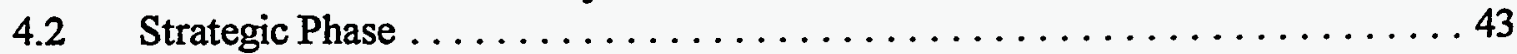

4.2.1 Formulate Feasible Alternatives . . . . . . . . . . . . . . 43

4.2.2 Evaluate Feasible Alternatives with Respect to Objectives . . . . . . . 47

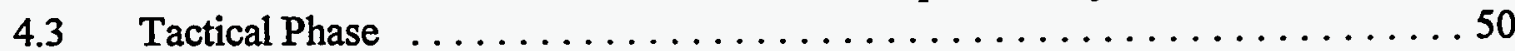

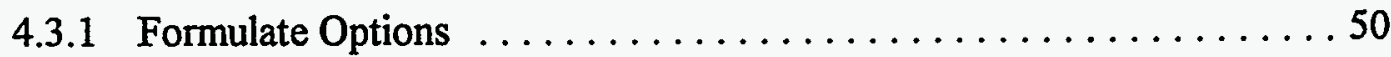

4.3.2 Evaluate Options with Respect to Objectives ............. 52

5.0 Elements to be Considered in Follow-on Work and Proposed RFP . . . . . . . . 56

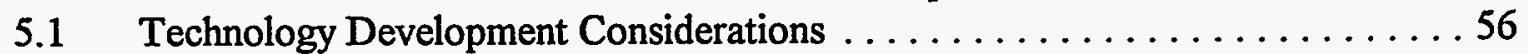

5.2 Business Approach . . . . . . . . . . . . . . . . . . . . . 57

5.2.1 Financing and Office of Management and Budget (OMB) Scoring . . . . 57

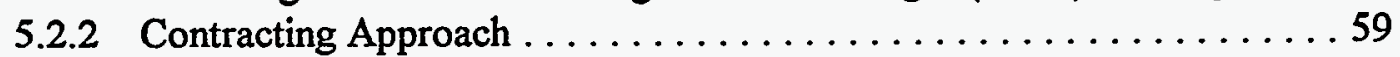

5.2.3 Other Contracting Considerations ...................61

5.2.3.1 Sole Source vs. Competition ...............61 61

5.2.3.2 Terms and Conditions $\ldots \ldots \ldots \ldots \ldots \ldots \ldots 6.61$

5.2.3.3 Liability and Contract Clauses $\ldots \ldots \ldots \ldots \ldots \ldots 62$

5.1.3.4 Price Anderson Considerations . . . . . . . . . . . 63

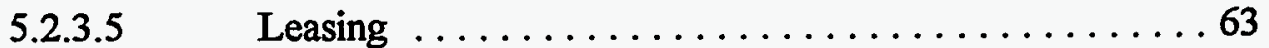

5.2.3.6 Interest vs. Cost of Money . . . . . . . . . . . 63

5.2.3.7 Procurement Schedule ..................64 64 
5.2.3.8 Organizational Conflicts of Interest $\ldots \ldots \ldots \ldots .64$

5.3 Labor Considerations . . . . . . . . . . . . . . . . . . . . . . 64

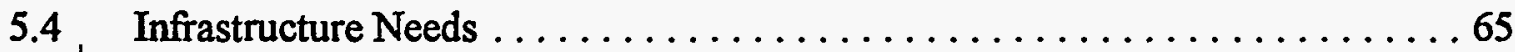

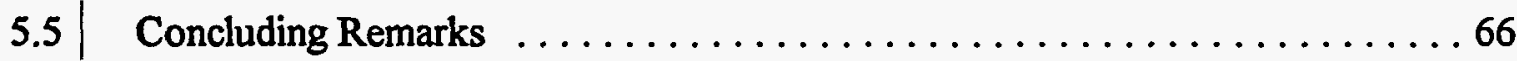

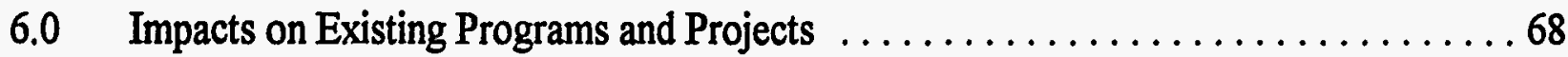

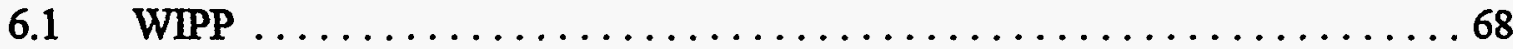

6.1.1 National Potential Implications to the TRU Waste Program .......68

6.1.2 Impact of INEL Decision to Treat TRU on the WIPP "No Migration Petition" .................................... 72

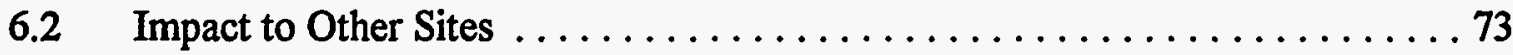

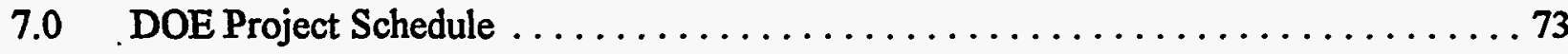

8.0 Next Steps/External Communications Plan and Approval Plan $\ldots \ldots \ldots \ldots \ldots$

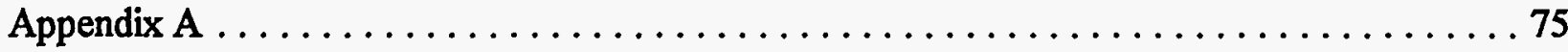

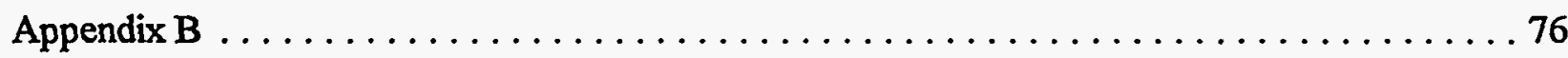

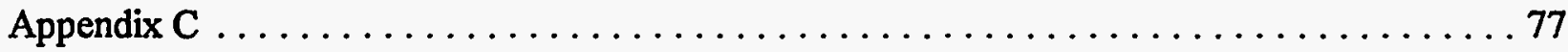

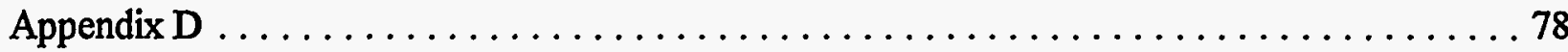

\section{Tables}

Table 3-1. Contracting arrangements $\ldots \ldots \ldots \ldots \ldots \ldots \ldots \ldots \ldots \ldots \ldots \ldots \ldots \ldots \ldots \ldots$

Table 3-2. Unit Prices for Treating ALLMW and TRU. $\ldots \ldots \ldots \ldots \ldots \ldots \ldots \ldots \ldots$

Table 3-3. Treatment Cost Comparisons (FY-94 millions) . . . . . . . . . . . . 39

Table 3-4. Alternative Plans for TRU and Alpha Contaminated Waste ............ 41

Table 4-1. Treatment Alternatives with Respect to Objectives. .............. 47

Table 4-2. Evaluation of Feasible Options with Respect to the Objectives. . . . . . . . 53

Table 6-1. Alternative Plans for TRU and Alpha Contaminated Waste. ........... 71

Table C-1. Total Alpha and TRU Quantities in Complex and Projected Facility Costs . . . 77

\section{Figures}

Figure 4-1. Overview of Decision Making Process $\ldots \ldots \ldots \ldots \ldots \ldots \ldots \ldots \ldots$

Figure 4-2. Overview of Tactical Phase of Decision Making Process. ............ 44

Figure 4-3. Baseline M\&O IWPF Concept: Treat Alpha and TRU Separately . . . . . . 46

Figure 4-4. Private Sector Concept: Treat Alpha and TRU Together $\ldots \ldots \ldots \ldots \ldots . .46$ 
Figure 4-5. Overview of Tactical Phase of Decision Making Process . . . . . . . . . 50

Figure 4-6. Conceptual Context of Private Sector Involvement .............. 55

Figure 5-1. Expected Contract and Funds Flow. . . . . . . . . . . . . . 59 


\section{EXECUTIVE SUMMARY}

The INEL currently stores approximately 27,000 cubic meters of alpha contaminated low level waste (ALLMW) and 38,000 cubic meters of transuranic waste (TRU) at the Radioactive Waste Management Complex (RWMC). Virtually all of this waste is also contaminated with Resource Conservation and Recovery Act (RCRA) hazardous materials and is therefore classified as mixed waste. Some of the waste also contains Toxic Substance Control Act (TSCA) regulated materials.

The current INEL baseline plan is to treat ALLMW to meet RCRA Land Disposal Restrictions (LDR) standards and to repackage/treat the TRU waste to meet the Waste Isolation Pilot Plant (WIPP) Waste Acceptance Criteria (WAC). This treatment and repackaging would be done at a planned Line Item Construction Project facility that would start operations no earlier than 2010. This Line Item Project has an estimated life-cycle treatment cost of approximately $\$ 620 \mathrm{M}$ (FY94\$). Using this treatment facility the total life-cycle cost for INEL stored waste from retrieval through transportation to a disposal site is $\$ 1.6 \mathrm{~B}$ (FY-94\$).

Previous work at the INEL indicated that the private sector had the interest and capacity to treat ALLMW. It was anticipated the private sector treatment approach could be more cost and schedule effective than the INEL baseline plan. In May of 1994, DOE-ID provided funding for three private sector teams to prepare feasibility studies on this subject. These studies developed technical, regulatory and business plans for potential private sector treatment of INEL stored waste. The teams were headed by Lockheed Environmental Systems and Technologies Company (LESAT), Rust Federal Services, Inc., and the Scientific Ecology Group (SEG). The studies were directed at ALLMW, but were allowed to address other waste types and non-INEL waste sources. !

A DOE-ID team evaluated the completed feasibility studies. The team determined that all three private sector solutions were technologically feasible and that the private sector's rates of return on investment were reasonable. Cost projections show private sector treatment could save the DOE \$215M (FY-94\$) in treatment costs and \$820M (FY-94\$) in overall life-cycle costs, while completing disposal eight years earlier than the current baseline plan.

The evaluation team concluded that:

1) Private sector treatment of both INEL ALLMW and TRU to LDR standards is the most effective option.

2) A DOE regulated treatment facility located on $\mathrm{INEL}$ leased land was preferable to an off-site location. 
The evaluation team recommends that:

1) A competitive procurement for private sector treatment be pursued, including options for private sector retrieval and storage.

2) The current plans for a line item treatment facility be terminated.

3) DOE-ID should lead an effort to examine the benefits of regional treatment opportunities with other western DOE Operations Offices.

A contract could be awarded in FY-97 allowing a private facility to begin operations in FY-03. 


\section{Acronyms}

ALARA as low as reasonably achievable

ALLMW alpha low level mixed waste

ANL-E Argonne National Laboratories - East

BNFL British Nuclear Fuel Incorporated

CERCLA Comprehensive Environment Response, Compensation and Liability Act

COM cost of money

D\&D decontamination and decommissioning

DOE Department of Energy

DOE-ID Department of Energy - Idaho Operations Office

EIS Environmental Impact Statement

EPA Environmental Protection Agency

ER environmental restoration

ER\&WM Environmental Restoration and Waste Management

EH Office of Environment, Safety and Health

FAR Federal Acquisition Regulation

HQ Headquarters

INEL Idaho National Engineering Laboratory

IWPF Idaho Waste Processing Facility

KAPL Knolls Atomic Power Laboratory

LBL Lawrence Berkeley Laboratory 
LDR Land Disposal Restrictions

LESAT Lockheed Environmental Systems and Technologies Company

LITCO Lockheed Idaho Technologies Company

LLNL Lawrence Livermore National Laboratory

M\&O Management and Operations

MSE Mountain States Energy Incorporated

NEPA National Environmental Policy Act

NRC Nuclear Regulatory Commission

NTS Nevada Test Site

OCI organizational conflict of interest

OMB Office of Management and Budget

ORNL Oak Ridge National Laboratory

OSHA Occupational Safety and Health Administration

PANTEX Panhandle of Texas

PCB polychlorinated biphenyl

PHP plasma hearth process

PS private sector

RCRA Resource Conservation and Recovery Act

RE Retrieval Enclosure

RFP request for proposal

RFP Rocky Flats Plant

RWMC Radioactive Waste Management Complex 


\begin{tabular}{ll} 
SAIC & Science Applications International Corporation \\
SDA & Surface Disposal Area \\
SEG & Scientific Ecology Group \\
SNL & Sandia National Laboratories \\
SOW & statement of work \\
SRS & Savannah River Site \\
SWEPP & Stored Waste Examination Pilot Project \\
T\&C & terms and conditions \\
TRU & Transuranic \\
TRUPACT & Transuranic Package Container/Transporter \\
TSA & Transuranic Storage Area \\
TSCA & Toxic Substance Control Act \\
U of MO & University of Missouri \\
WAC & Waste Acceptance Criteria \\
WCF & Waste Characterization Facility \\
WETO & Western Environmental Technology Office \\
WIPP & Waste Isolation Pilot Plant \\
WVDP & West Valley Demonstration Project \\
\hline
\end{tabular}




\section{DOE Idaho Operations Office \\ Evaluation of Feasibility Studies for Private Sector Treatment of Alpha and TRU Mixed Waste}

\subsection{Introduction}

\subsection{Waste Description}

The INEL has a need for treatment of approximately 27,000 cubic meters $\left(\mathrm{m}^{3}\right)$ of ALLMW presently located in retrievable storage at the Transuranic Storage Area (TSA) of the RWMC. The majority of the waste is located in earthen-covered storage at TSA, with the remainder located in the Certified and Segregated Building and the Air Support Building at RWMC. This waste is currently referred to as "alpha low-level" waste or "reclassified transuranic waste" because of its original classification as TRU waste. The earthen-covered stored waste is frequently referred to as "bermed"waste.

Containers of this waste are co-located with $38,000 \mathrm{~m}^{3}$ of TRU wastes. Most of these wastes (>95\%) are from operations at the Rocky Flats Plant received since 1970. Similar Rocky Flats Plant wastes were buried in the Subsurface Disposal Area (SDA) of the RWMC prior to 1970. The stored TRU and ALLMW are physically and chemically identical. The difference in the waste is the concentration of transuranic radionuclides (TRU has greater than $100 \mathrm{nCi} / \mathrm{g}$ of transuranic nuclides by current definition, while alpha has less than 100). The INEL has approximately $60 \%$ of the stored alpha and TRU waste inventory in the Department.

Approximately $95 \%$ of these wastes are contaminated with RCRA regulated hazardous wastes and are, therefore, categorized as mixed wastes (radioactive and hazardous). Some containers have Toxic Substance Control Act (TSCA) regulated materials such as polychlorinated biphenyls (PCBs) and asbestos.

Fifty-eight percent (58\%) of the waste is contained in boxes and bins, with the remaining $42 \%$ contained in drums. Based upon examination of limited samples of waste containers, the content code descriptions are believed to accurately represent the types and overall amounts of materials present. There are uncertainties, however, in the quantities and distributions of the materials within containers and among the containers. 


\subsection{Regulatory Status/Environment, Safety and Health Risk}

The waste stored in the TSA is mixed waste, regulated under the Atomic Energy Act and RCRA. As mentioned in Section 1.1, some containers also contain TSCA-regulated materials. The existing earthen-covered storage is a RCRA interim-status container storage unit. The Part B permit for interim storage of this waste has been submitted to the State of Idaho.

The Hazardous and Solid Wastes Amendments to RCRA require that all hazardous waste be treated to EPA standards before being placed "in or on the land" (40 CFR 268) for disposal. In addition the only permissible reason to store untreated waste is to "accumulate sufficient quantities of hazardous waste as necessary to facilitate proper recovery, treatment, or disposal" [40 CFR 268.50; RCRA Section 3004(j)]. This is referred to as the LDR storage prohibition. DOE interim storage of mixed waste does not satisfy these requirements, but is being allowed because treatment capacity for such wastes is not adequate or is unavailable at present.

The Federal Facility Compliance Act of 1992 requires the Department of Energy (DOE) to develop a treatment plan for each site that generates or stores mixed wastes. DOE's sovereign immunity to penalties with respect to EPA LDR storage prohibition violations for mixed wastes will not apply to DOE after October 1995, unless DOE is in compliance with both a treatment plan and an order requiring compliance with the treatment plan. A proposed site treatment plan has been issued for review (DOE-ID-10493, March 30, 1995).

The earthen-covered stored waste containers at the TSA and stored waste located in the Certified and Segregated and Air Support Buildings were also subject to an EPA Notice of Noncompliance dated January 29, 1990, for improper inspections and aisle spacing. The issue has not been resolved for waste in earthen-covered storage and is expected to be addressed in the planned consent order.

The waste has been in drums and boxes within the earthen covered berm since the early 1970 's. At the time of initial storage, the expected design life for the containers was 20 years. Some degradation and deterioration of containers and stored waste is expected, with associated soil contamination. If the waste is not dealt with in the near future, a significant quantity (up to $36,800 \mathrm{~m}^{3}$ ) of soil could also be contaminated. 


\subsection{DOE Budget Constraints}

There are presently no identified funds for a treatment project of this potential size. A recommended approach and overall life cycle funding needs are presented in this report.

\subsection{Relevant INEL Plans and Projects}

The TRU Waste Program at the INEL includes the retrieval, storage, assay, characterization, treatment/repackaging, and transportation for disposal of ALLMW and TRU. Private sector treatment would impact these operations significantly. In order to facilitate understanding, the current plans for these activities are briefly described below. A full description of these activities is contained in Section 3.9.

Current DOE strategy is to repackage and certify TRU wastes for shipment and disposal at the WIPP. This assumes WIPP will be granted a "No Migration Determination." The ALLMW is presently excluded from disposal at WIPP and will require treatment to LDR standards prior to disposal in some RCRA-permitted mixed waste disposal facility, which is yet to be identified.

A RCRA compliant retrieval enclosure is being constructed over the bermed waste. Waste will be moved from the earthen covered berm to RCRA storage modules. The RCRA storage modules will provide for interim waste storage consistent with RCRA requirements while awaiting treatment for final disposition.

The waste will be assayed in the Stored Waste Examination Pilot Project (SWEPP) to determine if the waste is alpha (requiring LDR treatment), or TRU (requiring treatment to the WIPP WAC). Plans are to send $10 \%$ of the TRU waste to the Waste Characterization Facility (WCF) (a planned Line Item Construction Project) to assure on a sample basis that the WIPP WAC requirements are met. Both the alpha and TRU wastes will be placed in RCRA compliant storage modules awaiting treatment or repackaging. The current INEL plan is to treat the ALLMW to LDR standards in the Idaho Waste Processing Facility (IWPF). The IWPF (a planned Line Item Construction Project) would also repackage or treat TRU waste as needed to meet the WIPP WAC. For the purposes of this report, the start date utilized for IWPF is 2010; however, current DOE budget constraints may delay the start date of IWPF well beyond 2010.

TRU waste will be transported to WIPP for disposal following WIPP opening in 1998. The baseline plan to treat ALLMW to LDR standards in the IWPF involves a thermal treatment process. That process has an $80 \%$ volume reduction and is expected to produce primarily a TRU final waste form which will be transported to WIPP. Mixed waste forms which are not TRU, e.g., secondary processing residues, will be disposed of at a facility permitted for mixed-LLW (which has not yet been identified). 
Estimated life cycle costs for the current baseline plans are \$1.6B in FY-94 dollars. This figure includes the cost of transportation to WIPP, but excludes any subsequent disposal costs.

\subsection{Feasibility Study Concept and Associated Request For Proposal (RFP)}

Based on earlier scoping studies and work by EG\&G Idaho [a previous INEL Management and Operating (M\&O) contractor] and the private sector, it was believed that the private sector had the general capability and interest to provide turn-key treatment services for the ALLMW stream. These studies indicated that the private sector could perform these services for substantially less cost than a M\&O contractor. Based on the scoping studies, particular technical, regulatory, and financing issues required further development on the part of industry before proceeding with a private services treatment procurement. DOE-ID decided to fund feasibility studies by the private sector for ALLMW treatment services. This was done to obtain more specific information from capable, potential suppliers on private treatment service solutions and provide a stronger basis from which to develop a successful procurement.

On December 15, 1993, DOE-ID published and released a "Statement of Work (SOW) for a Feasibility Study of Treatment Services for Alpha-Contaminated Mixed Low-Level Waste." The document established DOE-ID's intent to purchase several feasibility studies on private sector solutions for the future treatment of ALLMW. Innovative approaches for providing all aspects of the treatment services were encouraged. The request for feasibility studies was identified as the initial step anticipated to lead to an eventual procurement for production treatment services with the best ideas selected from among the studies and used in a follow-on RFP.

DOE-ID's expressed intention in the feasibility study RFP was to obtain industry's "best thinking" for a private sector approach to cost effective waste treatment. The RFP indicated that teaming arrangements for preparation of the studies were preferred; that partners should have experience in design, construction, and operation of actual waste treatment facilities; and would need to demonstrate the ability to finance such a treatment services project.

Assumptions/direction provided in the RFP indicated the private sector should assume:

- They would own and operate the facility, would be responsible for all licensing and permitting, and would operate within applicable Federal and State rules and regulations. DOE orders were not invoked; rather, the private sector was asked to identify whether they would be DOE regulated, or NRC licensed.

- They would assume risk and liability. 
- They could consider using existing facilities on the INEL or off-site, within Idaho, or in another part of the U.S. (key driver was cost effectiveness).

- They needed to provide information on options considered, why options were rejected, and the rationale for their recommended approach.

- They could treat non-INEL waste (including commercial waste) but residuals would have to be returned to the generator for disposal.

Study deliverables included a Business Plan, with financial approaches, recommendations on the type of contract and contract terms and conditions, cost estimates, pricing to DOE, and a schedule for treatment services; a Technology Plan; a Licensing and Regulatory Plan; a Transportation and Waste Transfer Plan; and a Public Acceptance Plan.

Three highly capable private sector (PS) teams ultimately provided feasibility studies for DOE-ID consideration. The PS teams (in alphabetical order) were: Lockheed Environmental Systems and Technologies Company (LESAT); Rust Federal Services, Incorporated; and the Scientific Ecology Group (SEG).

The LESAT team included Mountain States Energy, Incorporated (MSE). The Rust Federal Services study team included Science Applications International Corporation (SAIC), Martin Marietta Aerospace and Naval Systems, and Consoer, Townsend and Associates. The SEG study team included British Nuclear Fuels Incorporated (BNFL), Raytheon Corporation, and Morrison-Knudsen Corporation.

The focus of the treatment service feasibility studies was ALLMW stored at the TSA of the INEL. Optionally it was suggested that treatment of TRU waste stored at the TSA, similar environmental restoration (ER) buried wastes at the SDA, and other similar DOE site wastes might be considered as expanded waste treatment markets for a given treatment facility depending upon technologies/services available at the facility.

The SOW for the feasibility studies, and attendant supplied reference reports (EGGRWMC-11189 and 11190 March 1994), provided a detailed description of the stored wastes (both ALLMW and TRU) at the RWMC TSA. The SOW also described the presently envisioned treated product waste acceptance criteria in functional performance terms, but did not require a specific type of product material. As a minimum the treated product waste materials have to satisfy the requirements for RCRA and TSCA long term storage and disposal, and provide suitable performance properties for passing a DOE radiological disposal site performance assessment. Additional detailed specifications on desired waste form materials performance properties were also supplied in the SOW as a guide, but were not required. The selection of treatment processing system technologies, and resulting treatment products (final waste forms) was left up to the feasibility study suppliers. 
All three providers of feasibility studies were considered responsive to the published SOW. Each supplier provided all required plans and descriptions; however, the level of detail provided varied. The extent of each study was generally consistent with each supplier's accepted proposal and the contracted study compensation level. It is important to note this differing level of contracted scope and compensation when reviewing each study. The feasibility studies were conducted over a period of six months and underwent a DOE-ID draft review and revision sequence before completion to current form.

DOE-ID recognizes that in the current dynamic business climate, the consortia which prepared the studies may or may not emerge as eventual bidders. Nevertheless, the studies have provided a private sector, business-based insight into resolving this significant waste management challenge.

\subsection{Conclusions and Recommendations}

Based on an evaluation of the private sector feasibility studies, and an evaluation of current baseline plans for alpha and TRU mixed waste treatment, the DOE-ID Evaluation Team has drawn the following conclusions:

- Private sector treatment of INEL alpha and TRU mixed wastes to Land Disposal Restrictions is the most cost effective option; life cycle cost savings are expected to be approximately $\$ 820 \mathrm{M}$.

- An on-site DOE regulated treatment facility near the RWMC on leased land would be the most cost and schedule effective location.

- A competitive procurement conducted by DOE-ID for waste assay, characterization, and treatment, with options on private sector retrieval and storage is the best approach .

- There is great potential cost savings to the Department in a regional/national treatment approach for alpha and TRU waste needing treatment for disposal at WIPP, which must be explored further.

This evaluation process has led to DOE-ID confidence in a privatized approach. Consequently, it is recommended that the planned Idaho Waste Processing Facility Line Item Construction Project be eliminated as an alternative at this time. DOE-ID should proceed with the privatized approach, and lead an effort to examine regional treatment opportunities with other western Operations Offices.

DOE-ID recognizes the importance of a well-defined RFP and technical SOW for the actual procurement of treatment services. During the feasibility study stage, selected business and technical issues were intentionally left open for interpretation by the private 
sector. Given the benefit of the private sector's input from the feasibility studies, DOE must decide upon its requirements for treatment services and clearly define these expectations in a future RFP. DOE expects that costs developed for the feasibility studies will change in response to an RFP for services. More restrictive requirements in the future RFP would tend to increase costs, but removing the uncertainty would tend to decrease the costs. In either case substantial savings in comparison to the current INEL baseline plan are expected.

\subsection{Summary of Private Sector Approaches and DOE Assessment of Approaches}

This section of the report provides a summary of the private sector treatment service approaches described in detail in each study. Each of the three studies is well over 400 pages, including numerous figures and tables. The following comparative study deals with key items only. DOE comments and assessments appear in italicized text.

\subsection{Baseline Technologies}

\subsubsection{Treatment Technology Screening}

In developing their waste treatment processing system scenarios, the SEG and Rust studies included basic treatment technology assessment and selection/screening studies. The LESAT study focused solely upon application of their Pit 9 environmental restoration (ER) buried waste processing demonstration system technology to the stored wastes. This was consistent with the scope of each contracted study.

Both SEG and Rust utilized similar technology design selection methods. Waste descriptions were reviewed and categorized, candidate technology options were identified for each category, decision objectives and criteria were defined, and candidate technologies scored against the criteria. Both studies independently led to similar waste categories and overall treatment system approaches, but specific technology components differed.

\subsubsection{Primary Treatment}

Each supplier provided a description of their selected waste processing system in terms of the key functional process activities and enabling equipment components. The block diagram process flowsheets for each of the study's recommended treatment systems, subsystems, and key components provide an overall view of the recommended treatment systems. From examination of these and the attendant descriptions of functional equipment components, a few key comparative observations can be made. 
All three feasibility study suppliers recommended treatment systems that involve a primary high temperature, thermal treatment for processing the large majority of the wastes. This approach provides for thermal destruction of the organic waste constituents, including the RCRA and TSCA hazardous compounds, and achieves substantial waste volume reductions. It also allows for acceptance of a wide range of uncertain, variable heterogeneous mixed waste for processing, while yielding a few homogeneous, readily characterized and acceptable product materials.

SEG's baseline system utilizes a fuel fired, rotary kiln incinerator with the resulting ash residues to be stabilized in pozzolonic portland cement grout as a final product material. In addition, SEG identifies several alternate equipment components which they discuss as being under development and evaluation for possible future use in place of their baseline technologies in the recommended system. In particular, SEG might utilize the rotary kiln in a slagging mode to produce a directly vitrified ash product or utilize a joule heated melter to vitrify the rotary kiln ash rather than use grout/cement stabilization, if a glass final waste form is required. SEG is also evaluating an induction heated steel bath waste processor (Molten Metal Technologies CEP); steam reforming (Synthetic Detoxifier Systems); and wet air oxidation (WETOX) as alternate primary thermal treatments to replace the rotary kiln incinerator. Polyethylene encapsulation was noted as a potential alternative stabilization media to cement, grout, or glass/ceramic. These alternate technologies are briefly described in the study. None of these alternate technologies are being relied upon at this time by SEG.

The Rust and LESAT systems use electric plasma arc torch heated furnaces of differing configurations to combust the organics and melt/dissolve the inorganic solids in a silica based slag which leads to a vitrified or glass/ceramic primary final product material. LESAT utilizes a plasma centrifugal reactor furnace/melter (a rotating hearth chamber), while Rust recommends a fixed hearth furnace/melter (non rotating chamber). Rust also recommends to remove some of the melted waste as a reduced melted metal rather than a glassy slag. Both plasma torch furnace/melter configurations are manufactured by Retech Systems of Ukiah California.

The feasibility siudies all centered on primary treatment via a thermal process, including one incinerator. Each of the three primary treatment technologies appears to be viable. The plasma technologies are currently less widely used and potentially require more development prior to full scale deployment for mixed waste. Recovery of reduced metals (Rust and SEG alternate, molten metal) as a separate stream may be economically advantageous because of avoidance of costs associated with storage, certification and transportation to WIPP. 
There is a concern about public acceptance of thermal technologies, particularly incinerators, which warrants continued monitoring of the developments in nonthermal treatments as alternatives to the primary thermal treatments. The definition of non-thermal treatment is somewhat subjective. Because of the current furor over the use of incinerators for waste disposal, many technology proponents will argue that a technology is not thermal or at the very least is not an incinerator, despite operation at elevated temperature and off-gas streams consisting of products of combustion. A variety of non-thermal treatments are in various stages of development, including molten metal, steam reforming, Delphi catalyzed wet oxidation, hydrothermal oxidation (a.k.a. supercritical water oxidation), molten salt, etc. In general these technologies require the feed to be liquid or ground to a fine particle size. They also may require a follow-on process to stabilize residues for disposal. Due to these restrictions, these technologies as a group are applicable to a narrower span of DOE wastes than the thermal technologies selected in the feasibility studies. SEG did list alternate technologies advertised as "non-thermal" (molten metal and steam reforming). The disadvantages in pursuing non-thermal options are that less volume reduction will be realized and that a greater fraction of the waste will not be treated.

\subsubsection{Off-gas Systems}

Each recommended system utilizes an off-gas treatment subsystem to satisfy emissions limits imposed by State and Federal laws and regulations. The specifics of each recommended off-gas system vary and the order in which components are incorporated can be important to the overall off-gas system effectiveness.

Each of the recommended high temperature, thermal treatment systems utilizes a secondary combustion chamber (conventional propane or natural gas fired) as part of the off-gas treatment system. The secondary combustion chamber ensures extra residence time at temperatures sufficient to complete combustion of the volatile organic compound gases pyrolized in the primary furnaces (rotary kiln or plasma torch furnaces). Of particular concern is the assurance of the destruction of chlorinated hydrocarbons such as PCBs, dioxins, and furans. This approach is essentially required in order to satisfy EPA requirements for off-gas treatment.

Each recommended off-gas system also includes a partial gas cooling/quenching step; a rough particulate filtering step (cyclone chambers and baghouse for dry/wet approach, venturi scrubbers for wet approach); a water based acid gas scrubbing and neutralizing step to eliminate acid gases (leading to secondary halogenated salt residues); a carbon absorber or mossy zinc filter for capturing volatilized mercury and residual organics; and a bank of High Efficiency Particulate Air filters for final particulate capture. 
These designs are very important and should be examined for their effectiveness, but all are essentially based upon existing workable technology components. There is an ongoing, DOE sponsored effort at the Western Environmental Technology Office (WETO) to develop off-gas system controls for thermal treatment processes which would allow real time monitoring and control of emissions via delayed release and/or closed cycle off-gas systems. Developments in this area should be closely monitored for potential application to ALLMW treatment.

\subsubsection{Material Handling}

Both SEG and Rust systems utilize an up-front physical waste sorting approach to segregate bulk metals, bulk lead, and high mercury content wastes for separate treatment from the majority of the wastes which pass on to the primary furnace. LESAT's system does not sort and segregate wastes at all; it simply size reduces (shreds) all incoming wastes and containers and passes them through the primary plasma torch furnace (plasma centrifugal reactor).

Upon receiving the wastes in containers, both SEG and Rust systems open, dump, and gross sort the waste contents into-several general categories for differing treatments. Sorting is done remotely by operators with robotic manipulators. SEG dumps and sorts all received containers, whereas Rust takes some well known drums (about $30 \%$ of the wastes) directly to the plasma hearth furnace; all others are dumped and sorted. This gross sort yields: (1) a primarily bulk metals stream (steel, etc.) which is suitable for surface decontamination via an acid/chemical wash technique or a solid (frozen) carbon dioxide pellet blast technique; (2) a bulk lead stream for similar surface decontamination; (3) mercury bearing wastes for separate treatment, such as thermal desorption or distillation, and bulk amalgamation, and (4) all the remaining mixed combustible and noncombustible wastes for thermal processing. Most of the waste volume will be thermally processed. SEG shreds the sorted wastes before thermal processing in the rotary kiln, while Rust uses a crusher/shear to size reduce some wastes as needed, redrums the sorted/sized materials and feeds the drummed wastes to the plasma hearth furnace. Bulk structural metals will be supercompacted by SEG following decontamination.

The LESAT system does not open containers for dumping and sorting of wastes at receipt. All waste materials, including containers, are shredded and processed through the plasma furnace. Following the shredder, a magnetic metal separation step is used allowing for later controlled staging and mixing of the ferrous metals into the plasma furnace with the remaining shredded feed. This allows for control of the iron content in the final glass/ceramic product. All shredded (<4-inch diameter) materials are processed in the plasma centrifugal furnace. The lead in a 
given batch of waste is expected to partition roughly $50 \%$ into the slag (as lead oxide) and the remainder will be volatilized for capture in the off-gas system and returned to the plasma furnace feed. Net capture after repeated cycles, with little lead in the total waste feed, is expected to yield all lead in the slag. Volatile mercury will not partition to the slag and the fate of mercury was not specifically addressed in the LESAT study, except for the inclusion of a mossy zinc filter in the off-gas system schematic.

The material handling section of any facility will require careful evaluation and design to ensure contamination confinement and muclear criticality safety. The material handling and sort area will also need to be evaluated relative to personal safety, particularly for maintenance and unscheduled activities, e.g., clearing shredder jams, sizing large equipment, etc.

The LESAT approach may require additional sizing equipment to size waste to fit a commercial shredder, i.e., opening waste boxes and handling large, irregular wastes, e.g., machine shop equipment, vehicles, etc.

\subsubsection{Assay Systems}

All three of the recommended treatment systems are utilizing nondestructive assay via passive neutron counting, active neutron counting, Segmented Gamma Scanning, and some form of the Imaging Passive and Active Neutron assay system technology, offered by Pajarito Scientific, for assay of wastes. Assay is required at several points in the processing systems for criticality control, for staging of wastes to tailor alpha concentration of the product material, and to assay and certify the final treated product material (final waste form).

The capability of these nondestructive, nonintrusive assay systems is representative of the state of the art. The specifics of the technical proof bases for each point of application of these technologies relative to the waste materials physical configuration and heterogeneity are issues which will require further review beyond the level addressed in the studies. Additional system development focusing on improved data processing schemes to speed up the non-destructive examination is ongoing at the INEL (Office of Technology Development [EM 50] Radiological Hazardous Materials Monitoring System project).

\subsubsection{Radiological and Hazardous Material Control}

Each of the feasibility studies addressed radiological and hazardous materials handling and control issues and features for the preconceptual treatment systems and facilities within the context of ensuring safety of operations and minimizing exposures to personnel, the public, and environment. The as low as reasonably 
achievable (ALARA) principle was noted as a guideline. Some features described in the design studies were remote operations for waste transfers, sorting, and sizing, preliminary shielding design, facility multiple confinement barriers and zones with negative pressure cascade, restricted access, limited ingress/egress, airlocks, personnel protective gear, standard radiological and hazardous contamination monitoring and decontamination, gloveboxes, smooth surfaces, strippable paints, and fissile content monitoring at various process points.

The SEG and Rust studies generally provided more descriptive information on the facilities, while LESAT provided more descriptive detail on the processing system components. Preliminary evaluations of fissile content limits for criticality control, preliminary radiation shielding calculations, and radiological and hazardous emissions evaluations were provided by SEG and Rust. Plans were included in each study for compliance with DOE orders or NRC requirements and EPA/State permitting requirements related to all areas of safety with emphasis on radiological safety. The LESAT study also included some detail on how maintenance in containment would be achieved for critical primary treatment system components (plasma torch and rotary chamber bearing).

Each of the studies addressed the issue of radiological and hazardous materials control to a level sufficient for early preconceptual feasibility study purposes. Each supplier is clearly aware of the importance of this issue and of the general conceptual approaches for successfully handling and controlling radiological contamination. However, none of the three studies developed and described a comprehensive, integrated program of consistently engineered facility and system features and concepts of operation sufficient to ensure the successful control of radiological and hazardous contamination in a production facility.

Control of facility emissions and the spread of contamination (and minimization of worker exposures) will be a critical factor in determining the ultimate success or failure of a production treatment facility. The development and integration of a comprehensive, contamination control program for every aspect of the process design and concept of operations for the facility will be essential. The studies do not appear to fully reflect the difficulties, impacts and challenges posed by contamination control in a production facility, particularly as they impact overall facility design, operations (movement of materials), maintenance, and decontamination and decommissioning.

In a follow-on RFP for services, the specification of selected sections of the DOE design criteria pertaining to contamination control for plutonium facilities (e.g., DOE Order 6430.1A Sections 1304-5, 1304-6, 1304-7, 1304-8) would be prudent. $A$ thorough description of the approach to developing a comprehensive, contamination control program as an integral part of the design should be 
required. Including the processing of TRU wastes within the scope of work for the treatment facility will substantially increase the potential inventory of alpha emitting radioactive materials in process streams, requiring more stringently engineered features and controls than for ALLMW alone.

\subsubsection{Criticality Control}

Each of the studies evaluated the potential for a nuclear criticality within the recommended treatment process. They generally concluded that criticality was not a concern, primarily on the basis of the total fissile mass. Methods for waste monitoring and control during processing to ensure avoidance of criticality conditions in the processing facilities were described. Although the focus of the studies was upon ALLMW, extension to TRU wastes was also addressed at the preconceptual level.

Each of the studies generally evaluated the potential for criticality based on expected waste materials and processing system inventories. Each study generally described methods for design and assurance of criticality control. Although generally sufficient for preconceptual feasibility studies, the discussions varied widely and lacked detailed consideration of process and chemical reactions that could concentrate fissionable material within piping or tanks (e.g., sludges in quench solutions used for off-gas treatment, buildup of fines in low points in pipes). Additional consideration for criticality control, and periodic sampling, inspection, or monitoring of important processes will need to be addressed in any final design. The determination that nuclear criticality is either a credible or incredible event will also play a decisive role in determining the hazard category and design criteria of the facility in accordance with DOE Order 5480.23. A decision to process TRU wastes, in addition to ALLMW, would increase both the mass of fissionable material being processed and the potential for nuclear criticality. Accordingly, additional engineered process features and administrative controls (e.g., inventory control, process sampling, component monitoring) will be necessary.

\subsection{Technology Development Plans and Requirements}

The SEG study baseline treatment system utilized processing technologies reported as "currently proven and demonstrated," therefore requiring no development. However, it was acknowledged that final waste form materials grout/cement formulations and process control plans would require additional consideration as part of the process system design. It was also noted that several alternate technologies for key system equipment components were identified by the SEG study as potentially promising and currently under development, with expected completion in the next six months to two years. The 
technologies are discussed briefly in the study, but no detailed task oriented development schedules were provided.

Although a fair amount of information was provided by SEG supporting the claim that the baseline technologies recommended (rotary kiln, portland cement grout stabilization, bulk metal surface decontamination, and bulk materials compaction) have been proven capable for the proposed mixed waste processing applications, further detailed evaluation and specification would be required. Although much confidence building representative data is available, full scale processing system/technologies have not, as yet, been fully demonstrated on the full range of actual transuranic contaminated heterogeneous mixed wastes of concern.

The Rust treatment approach identified two key technologies where development/demonstration was needed and planned. The first is the plasma hearth process (PHP) device that is presently under development/demonstration by Rust (SAIC) through funding being provided by the DOE Office of Technology Development (EM-50). The second is the application of the Vac*Trax vacuum based thermal desorption unit to desorb mercury for separate capture and amalgamation. A brief top level development plan was provided for each technology.

A PHP production scale cold test will be conducted at the Retech Facility in Ukiah, California by FY 96; bench scale hot testing to confirm the disposition of plutonium in the process will also be conducted in FY 96. Field scale hot testing will be conducted by the end of FY-97. Each plan is promising but needs further detailed evaluation and specification.

The LESAT treatment approach utilizes technologies that have undergone some proof of principle evaluations and will undergo a full scale demonstration as a part of the environmental restoration Pit 9 demonstration project. The LESAT feasibility study for the stored wastes indicates that LESAT considers the Pit 9 Limited Production Tests to represent the necessary technology development plan.

This approach, although having considerable merit, needs further detailed evaluation and specification in relationship to providing "proof of application" for stored wastes and ensuring an adequate permitting base.

The material handling processes recommended by all three studies appear to require more development to adequately address contamination control and ensure that personnel exposure is minimized in both operation and maintenance conditions. 


\subsection{Final Waste Forms}

According to the study the LESAT treatment system, utilizing the plasma centrifugal reactor, produces only an aluminosilicate glass/ceramic product material as a final waste form. The long lived alpha contamination of concern (primarily plutonium), as well as toxic metals, are captured as oxides in the glass/ceramic matrix. This material will either be $>100 \mathrm{nCi} / \mathrm{g}$ (TRU for disposal in WIPP) or $<10 \mathrm{nCi} / \mathrm{g}$ low level waste suitable for long term storage or disposal (still classified as "mixed waste" for disposal, due to the "derived from rule" unless DOE achieves delisting). Nearly all of the glass/ceramic product will be TRU since the actinides are selectively captured in this high-density material.

As noted above, it is known that mercury (highly volatile metal) cannot be captured in this glass/ceramic final waste form, so some amalgamated, nonradioactive mercury, secondary waste form material is likely.

The Rust treatment system, utilizing the PHP, produces a similar aluminosilicate glass/ceramic product as a primary treatment, final waste form product material, although the exact composition may vary. This material will again be managed to be either $>100$ $\mathrm{nCi} / \mathrm{g}$ or $<10 \mathrm{nCi} / \mathrm{g}$. The PHP melter furnace will also produce a separate molten metal phase consisting largely of reduced iron. This metallic phase is expected to be a radioactively clean material for release or recycle, or a very low level, non-actinide, radioactive material suitable for low level waste disposal. The Rust treatment system also produces surface decontaminated bulk structural metals and surface decontaminated bulk lead for release/recycle, and an amalgamated elemental mercury (with zinc) material for stabilization and disposal. Also produced will be very small amounts of portland cement for stabilization of bulk lead acid etch residue, and polyethylene for stabilization of scrubber blowdown salts with minor lead and cadmium content. All of the secondary waste forms are expected to be very low level wastes treated to LDR and suitable for disposal.

The SEG treatment system produces a pozzolanic portland cement grouted ash as the primary final waste form material. The pozzolanic cement is intended to stabilize the rotary kiln ash and is expected to meet RCRA toxicity characterization leaching procedure requirements and radiological disposal system performance assessment requirements. Alternatively, the SEG study suggests the rotary kiln ash can be encapsulated in polyethylene or vitrified (into a glass/ceramic material), if alternative primary final waste form materials other than portland based cement are required. Other primary product materials are surface decontaminated structural metals (supercompacted after decontamination via hydrosonic acid bath), surface decontaminated lead $\left(\mathrm{CO}_{2}\right.$ blast surface decontaminated), and amalgamated mercury. Secondary waste form materials produced for disposal are a grouted neutralized acid residue from the metal decontamination step, grouted asbestos and graphite, dried/concentrated crystalline 
scrubber salt residue, and minor miscellaneous grouted neutralized washdown area residues.

Each study provided typical values of engineering material properties for the treated products. Data provided are generally consistent with expected values based upon scoping studies.

Based upon the material properties reported in the feasibility studies, and considering preliminary radiological performance assessment studies (prepared by the INEL), all of the proposed primary final waste form materials have properties which will satisfy the EPA LDR and DOE performance assessments for a range of anticipated disposal site conditions. There are some potential "improved margin of performance" benefits possible for the glass/ceramic materials which are more mechanically and chemically durable than the pozzolonic portland cement grouted ash, and also result in greater volume reduction and homogeneity.

It should also be noted that the issue of expected range of final product material compositions as a function of waste stream variability and process control capability has not as yet been sufficiently addressed. Treated waste product specifications are likely to include material homogeneity, transuranic content, leachability, and other material properties. This is a detailed process engineering topic out of the scope of the present studies.

Several secondary waste form material products are produced by the SEG and Rust systems. No secondary waste form products are reported as being produced by the LESAT system (with the exception of the DOE-ID previously noted comment on mercury). The secondary waste form materials are primarily aimed at stabilizing small amounts of hazardous constituents, or very low level quantities of radionuclides.

It is expected that these materials will be acceptable as stated in the studies; however, additional detailed evaluations of the processes and specific secondary material product compositions will be needed. Controlling the processes to ensure that these secondary wastes are always low level waste $<10 \mathrm{nCi} / \mathrm{g}$ may not be practicable. This is more likely to be a problem processing TRU than for ALLMW.

There is a trade-off in whether metal debris is incorporated into the glass ceramic waste form (LESAT approach) or whether it is separated out for recycle. The feasibility studies include both approaches. The issue is trading operational simplicity against multiple waste streams to be handled and disposed. Recycling the metal is consistent with DOE's policies on waste minimization and pollution prevention However, the benefit of recycling the metal cannot be realized unless DOE is able to establish an internal market for the metal product or provide for free release of the material. 


\subsection{Volume Reduction}

The stated waste volume reductions are approximately $80 \%$ for the LESAT process, about $84 \%$ for the Rust process, and approximately $60 \%$ for the SEG process. The volume reductions for the Rust and SEG processes assume that surface decontaminated bulk metal can be recycled or free released. If this metal must be disposed, the total waste volume reductions for Rust and SEG are approximately $75 \%$ and $54 \%$ respectively.

It should be recognized that there is a good deal of uncertainty in these estimates. The key observation is that all the processes lead to substantial waste volume decreases for subsequent storage, handling, and disposal.

The thermal treatment of the combustible wastes, even without vitrification of ash, provides the majority of the net waste volume decrease in each process, and the vitrification/densification of noncombustibles (inherent in the plasma torch processes) leads to a significant additional volume decrease for the LESAT and Rust processes. SEG also obtains additional volume reduction from supercompaction of the surface decontaminated structural metals if they are not recyclable.

All three recommended approaches produce a TRU final waste form when treating $A L L M W$.

\subsection{Treatment Facility/Services Waste Acceptance Criteria}

All three suppliers recommended treatment services/facilities based upon technologies that would accept and treat essentially all of the known contact handled ALLMW as per the SOW detailed waste description.

The stored TRU wastes at the INEL would also be technically acceptable by LESAT, Rust, and SEG for treatment processing. Similar wastes from other DOE sites could also be treated, if transportable. Similar environmental restoration buried wastes, if retrieved, could be treated by all three systems, although SEG did not address treatment of contaminated soils, only the separated wastes.

A mixed waste treatment facility, as envisioned by each independent supplier's study, could technically be extended to a much larger market with minimal added capital investment, depending upon the throughput and schedules desired for processing. The business plans summarized elsewhere in this report show substantially reduced waste processing costs with increased waste market.

Detailed incoming waste acceptance criteria for each facility were provided and were similar in each case. These are listed in each study. Generally, the waste acceptance criteria identified in each study describe expected requirements for: (1) intact existing 
packaging (drums, boxes, or bins) or overpacks, (2) standard packaging sizes (exceptions would be accepted and dealt with on a case-by-case basis), (3) container identification, and (4) radiological and hazardous content identification, etc. Recommended treatment system technologies recommended in each study were selected with the intention that they tolerate the recognized waste variabilities and uncertainties in the waste description/characterization. Each treatment service facility incorporates waste assay and characterization capability necessary for the recommended treatment. Each treatment facility also includes sufficient waste assay and characterization capability to accept and process TSA stored wastes as presently described without further assay or characterization by the INEL.

\subsection{Treatment Facility Location and Transportation Issues}

The Rust and LESAT studies recommend location of the treatment facilities at the INEL within (or very near) the current RWMC. Neither explored the terms of a lease beyond a minimal cost to the contractor. SEG considers the option of a privately sited facility in more detail and for study purposes assumes a site near the INEL. The SEG study notes that because the majority of the waste to be processed is at the INEL, the "transportation costs and socioeconomic equity" tend to favor a facility at the INEL.

LESAT recommends the use/modification of the Pit 9 waste treatment demonstration facility site at the RWMC for the stored waste treatment. LESAT also examines, for business plan study cost comparison purposes, an alternative of constructing a new mixed waste treatment facility for stored wastes adjacent to the RWMC, if for some reason the Pit 9 demonstration facility site becomes unacceptable or unavailable for the stored wastes.

Both SEG and Rust examined the possibilities of siting the private facility off or on the INEL, including out of state. The out of state concept was rejected, largely due to perceived public acceptance difficulties and transportation problems. A common primary advantage noted for the onsite location relative to the INEL waste is the simplification of the waste transportation issue (local transfer potentially not even involving public roads versus mixed waste transfer across public roads). Another is public acceptance and socioeconomic benefits (existing site infrastructure and services, local familiarity with the site and its economic impact).

SEG minimizes the public transportation and public acceptance issues by assuming siting close to the INEL. SEG further believes the advantages of autonomy of a private treatment facility at a site close to the INEL may be substantial. Siting on private land would allow licensing of nuclear operations through the $\mathrm{NRC}$ process, which was perceived by the SEG team as a potential advantage. Also the siting of a private treatment facility on DOE leased land at the INEL is perceived by SEG as a "first" with the potential 
for considerable delays in developing the lease and private operator DOE oversight/interface relationships.

In contrast, Rust perceived little advantage to off-INEL siting. Rust suggested that DOE could lease land to the private sector and that there was no advantage to licensing by the NRC. They further suggested that DOE has more experience with alpha handling facilities, and both agencies might become involved making the licensing process more difficult for an off-site location.

Shipment of $A L L M W$ is not expected to present regulatory difficulty providing the activity level in the alpha waste containers fall below the DOT Type B quantity. Type A packaging requirements are much less stringent and the physical packaging is less stout than Type B packaging. It is anticipated that untreated alpha waste will be shipped as low level waste in Type A containers. Treated waste $<10 \mathrm{nCi} / \mathrm{g}$ has no significant shipping issues.

Transportation of drummed waste is expected to comply with applicable NRC and DOT regulatory requirements for packaging and shipping. The availability and capacity of existing certified packages for TRU waste is limited. TRUPACT II is currently the only certified transport package container permitted for transport of TRU waste. Some drummed waste contains activity in form and quantity which prohibits use of the TRUPACT II shipping container as the certificate of compliance is written today. A modification to the certificate for the TRUPACT II to allow a broader payload range is a reasonable option but may be time consuming $(2$ years + ) and require additional analyses for the Safety Analysis Report for Packaging.

Transportation of excavated boxes of TRU waste to an off-site treatment facility would be difficult due to the unavailability of a box transport system certified by the NRC. TRUPACT II will accommodate two standard waste boxes which are smaller and of different dimension than the bermed waste boxes. Shipping of boxed waste in compliance with current DOT regulations would require repackaging the waste material into existing certified containers such as the TRUPACT II standard waste box or designing and certifying a new container suitable as an overpack for the waste boxes. This would require design and construction of a repackaging facility. Another option would be to design and certify a new container suitable as an overpack for the waste boxes. The process for the latter option is expected to take between five and ten years; the cost estimate for this process in 1989 dollars was \$150M.

In general, location of the treatment facility on-site would allow the transport of waste material at the least cost and with minimal impact from outside regulators, and would likely be more acceptable to the public. In the current regulatory climate, packaging of material for transport that does not traverse public access roadways, must meet local $D O E$ requirements instead of NRC and DOT regulatory requirements. ADOE approved 
transport plan provides for equivalent safety (DOE Order 5480.3), thus meeting the intent of the DOT regulations.

\subsection{Processing Schedule Summary}

The LESAT study assumed that a services contract would be released in January of 1995 . Rust assumed award in June of 1995. SEG assumed award in November of 1995.

All of these assumed award dates are unrealistically early; however, they were used for the cost comparisons presented in Section 3.14. The actual proposed schedule and award dates are discussed in Section 7.0 of this report.

The LESAT study shows ALLMW processing beginning in 1998 and completing five years later in 2003. The processing operations schedule is 7 days a week, three shift operations, with an annual capacity of $4,247 \mathrm{~m}^{3}$. This plan does not match with current retrieval plans for stored wastes.

The Rust study shows ALLMW processing beginning in 2000 and completing five years later in 2005. The processing operations schedule is 7 days a week, three shift operations, with an annual capacity of $5,097 \mathrm{~m}^{3}$. This plan does not match with current retrieval plans for stored wastes.

The SEG study shows ALLMW processing beginning in 2001 and completing eight to nine years later in November 2009. The processing schedule is five days a week, single shift operations, with an annual capacity of $3,002 \mathrm{~m}^{3}$ (which is only half of the SEG facility design capacity). This mode of operation is scheduled to effectively match up with the current INEL stored waste retrieval plans.

Considering these studies, the ability of the INEL to retrieve and stage wastes for a private sector treatment facility will become the critical path for a waste treatment processing schedule. The studies clearly show that a private treatment service could be put in place more rapidly than the current INEL waste retrieval forecasts could supply waste. The LESAT and Rust studies treatment schedules would require a more rapid retrieval by the INEL than is currently planned. The SEG study purposely matched to the INEL schedule, but only required half design capacity and a one shift schedule. By comparison, internal studies on the line item IWPF project show the IWPF would start operations in 2010 and would complete processing in 2020 (again, this date has been even further delayed at the time of this report).

It is not clear at present what the latest allowable waste treatment processing end date might be. The feasibility studies indicate what the earliest possible schedule might be, if INEL waste retrieval (and assay) can be matched to the treatment facility earliest availability. The required completion date for INEL waste processing is not presently 
defined and, the scope/volume of waste processing (ALLMW, TRU, ER, Regional Wastes, etc.) is an important variable for treatment facility sizing, costing, and schedule.

As described in Section 1.1 of this report, the stored containers of ALLMW are colocated with stored TRU waste. ALLMW and TRU waste will be retrieved simultaneously. The current INEL plan is to begin retrieval operations in October 1996 (cost estimates in the report use a start date of Jamuary 1997), at a rate of approximately 10,000 drum equivalents per year. With the addition of a second shift in January of 2000 , the retrieval rate will double to 20,000 drum equivalents per year. On this planned retrieval schedule, all of the waste is not available for treatment until late in year 2010. If the retrieved waste was immediately available for processing, private sector facilities with the recommended annual capacities could complete treatment of the ALLMW in . 2011 or 2012. However, the current plan to segregate the ALLMW and TRU is constrained by the capacity of the INEL's SWEPP to assay the retrieved waste. At the planned SWEPP operating and staffing levels, private sector treatment of ALLMW would not be complete until 2014 to 2016.

All three feasibility studies evaluated the treatment of stored TRU waste to the same LDR standard as the ALLMW. Two of the studies extended the operating life of the facility recommended for ALLMW and the third study operated the recommended ALLMW facility at its design capacity rather that the capacity recommended to treat only the ALLMW quantity of waste. If the retrieved waste was immediately available for processing, the recommended private sector processing facilities could complete treatment of the ALLMW and TRU waste in 2012 or 2013. If it is still necessary to assay the waste at SWEPP under this treatment scenario, the completion dates would be between 2014 and 2016.

\section{$3.8 \quad$ Retrieval}

Although not requested in the RFP, one supplier indicated the ability and interest to perform waste retrieval operations. The retrieval process in this case refers to the bermed waste which is $80 \%$ of the total stored waste volume. A retrieval enclosure (referred to as the TSA-RE) is being constructed over the stored waste berm. The private sector supplier indicated they could use this facility, and perform all retrieval operations.

The current INEL approach envisions $M \& O$ retrieval to be started earlier than treatment in the IWPF. This results in creation of a substantial inventory of waste in interim storage. Combining the treatment with "just in time" retrieval could reduce or eliminate the interim storage need. Combining the retrieval and treatment contracts would also eliminate a great potential for interface difficulties and claims due to failure to deliver waste in either a timely manner or within written specifications for treatment acceptance. The storage modules would provide space for the operator to establish a working inventory prior to treatment. 


\subsection{INEL TRU Waste Program Impacts/Description of IWPF Base Case}

The TRU Waste Program at the INEL includes the retrieval, storage, assay, characterization, treatment/repackaging and transportation to disposal of ALLMW and TRU. Before examining the impact of private sector treatment on the program, the current plans for each of these major processes are discussed.

Approximately $20 \%$ of the retrievable stored ALLMW and TRU waste of the INEL is located in two air support buildings This waste is in the process of being moved to RCRA compliant storage buildings. The relocation will be complete prior to January 1,1998 , to meet a State of Idaho Consent Order. The remaining $80 \%$ of the stored waste is under earthen or geofabric covers. The retrieval plan is discussed in Section 3.7.

In anticipation of a possible procurement of private sector waste treatment services, the INEL evaluated the impact of an accelerated M\&O retrieval program. This evaluation was performed in 1993. The resulting study, "Operational Implementation Plan for Commercial Treatment of Alpha-LLW," (EGG-WM-10779, May 14, 1993) estimated that it would cost over $\$ 286 \mathrm{M}$, plus escalation and contingency, to significantly accelerate the stored waste retrieval. The benefit of implementing this plan did not appear to justify the estimated cost.

After retrieval the waste containers will be placed in a RCRA compliant Type II storage building. On average, each building can store about 19,320 drums or 2,640 boxes of waste. Seven Type II buildings are complete or planned for construction at this time. One of them is reserved for the Environmental Restoration Program at the INEL. As the need for additional storage becomes more certain, additional Type II buildings will be constructed. The baseline strategy plans to treat ALLMW to LDR and treat/repackage TRU waste to the extent necessary to meet the WIPP WAC. Assuming WIPP opens on schedule in 1998, this strategy requires eleven Type II storage buildings in addition to the six provided in the current construction plan.

The waste is assayed and examined in the SWEPP facility to segregate ALLMW and TRU waste and to verify compliance with sections of the WIPP WAC. This facility is scheduled to resume operation in FY-97 and to go to multiple shift operations a year later. SWEPP is planned to be upgraded for box assay in FY-02. The operating capacity is 5,000 drums, or 1,667 boxes per shift year.

The Waste Characterization Facility is planned to begin operation in FY-99 at a capacity of 1,000 drum equivalents per year, with one shift operations. This facility provides opening, sampling and verification capabilities to meet the WIPP waste characterization requirements. Additionally, the facility has limited treatment capability, the ability to handle oversized boxes, and it will be used to characterize waste to meet the State of Idaho RCRA Part B storage requirements. 
The current INEL plan is to treat the ALLMW to LDR standards in the IWPF. The IWPF would also repackage or treat TRU waste to meet the WIPP WAC.

TRU waste would be transported to WIPP following the opening of the WIPP facility in 1998. At the IWPF production level, the INEL would ship four transporters per week to WIPP. Each transporter can carry three TRUPACT II shipping containers. The baseline plan to treat ALLMW to LDR standards in the IWPF involves a thermal treatment process. That process has an $80 \%$ volume reduction and is expected to produce a TRU final waste form, which will be transported to WIPP. Secondary processing waste forms which are not TRU must be disposed at a DOE facility permitted for mixed low level waste (not yet identified).

As expected, the three private sector feasibility studies would have a major impact on the current INEL TRU program plans. One of the studies offered a completely different retrieval process. Although it was neither requested nor offered in the feasibility study SOW, all three contractors may be interested in privatizing the retrieval process as designed and constructed by INEL. This would eliminate the retrieval-treatment interface between the current INEL M\&O and the private sector.

With their start dates years in advance of the planned IWPF, the private sector scenarios would require fewer Type II storage buildings. The baseline INEL plan requires eleven new buildings (total of 18, with 17 designated for waste management use). The private sector alternatives would require no more than two additional storage buildings (total of nine, with eight designated for waste management use). A privately owned facility would have the necessary assay and characterization capability to assure compliance with its operating permits and to assure the necessary degree of safety. These capabilities may duplicate planned INEL capabilities (SWEPP and WCF). The private sector treatment schedules make the waste available to ship to WIPP much earlier than the baseline plan. To take advantage of this opportunity, the transport capacity to WIPP must be doubled from four to eight transport shipments per week. Cost analyses in this report include capital dollars to increase this transportation capacity. The alternative is to store the waste in available space until transport capability is available at the planned rate.

\subsection{Regulatory Authority/Approach}

Each of the studies identifies all the licensing and permitting requirements for the recommended treatment facilities. All of the identified requirements and licensing authorities are basically the same from an EPA regulations standpoint. All permitting under RCRA is administered by the State of Idaho, consistent with EPA standards and guidelines. A RCRA Part B Permit for hazardous waste storage and treatment facilities will be required. The State has primacy for the Clean Air Act, including the Permit to Construct and Permit to Operate; and cultural resource clearance. Permitting under Toxic Substance Control Act (TSCA) requires licensing approval by the EPA Region X, but 
most of the substantive tasks/information are the same as required and developed for the RCRA permitting. The EPA also approves National Emissions Standards for Hazardous Air Pollution Standards' compliance.

The siting of the ALLMW treatment facility on the INEL (as suggested by LESAT and Rust) will result in DOE being the regulatory authority for compliance with requirements under the Atomic Energy Act. Such an on-site location would also require DOE to perform the appropriate NEPA studies. SEG's off-site private siting approach may result in licensing by the Nuclear Regulatory Commission (NRC). If, in fact, NRC were to have licensing authority over such a facility, NRC would have corresponding NEPA responsibilities, with DOE likely acting as a cooperating agency in order to satisfy DOE's NEPA obligations related to the contract. NEPA requirements are discussed in greater detail in Section 3.10.4

The studies examine the specifics and schedules required to obtain each permit or compliance approval. A key conclusion is that the RCRA Part B and TSCA final approvals, which require production facility trial burns, are the critical path permitting items. The system engineering and RCRA permitting process is forecast to take roughly five years from start of the project by SEG and Rust. If the project were to begin January 1,1996 , the RCRA permitting would be completed in early 2001 for the start of mixed waste processing.

The LESAT approach for modification of the Pit 9 bermed waste demonstration and production facility to function under Comprehensive Environment Response, Compensation and Liability Act (CERCLA) is expected to lead to a more rapid concurrent permitting process for stored waste application under RCRA/TSCA (three years duration), largely as a result of the information in place for the CERCLA Applicable or Relevant Appropriate Requirements and the Pit 9 demonstration/production serving as part of the trial burn required for the modified Pit 9 facility. The LESAT study shows permitting completed in early 1998 for the start of mixed waste processing.

The DOE evaluation of the studies will address each regulatory aspect separately.

\subsubsection{Licensing Requirements}

If the private sector treatment facility is located on the INEL and is operated pursuant to a prime contract with DOE and treats only DOE waste, the contractor will not need an NRC license.

If the private sector contractor desired to treat off-site commercial mixed waste as part of its own business objectives (as opposed to at the request of DOE), it would be necessary for the contractor to obtain an NRC license as prescribed in 10 CFR 70.11. This section states: 
Any prime contractor of [DOE] is exempt from the requirements for a license. and from regulations in this part to the extent that such contractor UNDER HIS PRIME CONTRACT WITH [DOE] . . acquires ... receives, possesses... special nuclear material for: (a) The performance of work for [DOE] at a [DOE]-owned or controlled site ... (Emphasis added)

In addition, the contract will need to clearly provide that DOE's waste must be segregated from the commercial generator's waste because (i) any commingling of waste could expose DOE to extensive CERCLA liability if the ultimate place for disposal of the commercial waste ends up being a Superfund site, and (ii) DOE cannot possibly extend Price Anderson indemnification for nuclear incidents relating to the contractor's treatment of commercial waste.

\subsubsection{DOE Orders}

If DOE is the regulator for the radiological/radionuclide component of an $A L L M W$ facility, DOE needs to identify the specific requirements that define the "universe of applicable regulations." Applicable nuclear safety regulations are contained in Title 10 of the Code of Federal Regulations. However, the applicable DOE orders and standards have not been specifically identified. Note that DOE-HQ is working on this in the form of the Manual of Functions, Assignments, and Responsibility for Nuclear Safety, which is in draft form now. This manual does not address specific technical standards related to nuclear safety. A lesson learned from the other INEL projects is that before the RFP is issued, DOE must first identify the applicable orders, Code of Federal Regulations, and standards by which the contractor will be regulated. Otherwise, there is uncertainty and the potential for multiple, overlapping requirements, which would likely lead to cost increases under any contracting scenario.

As the regulator, DOE would be required to conduct an appropriate level of oversight. Past experience has shown that DOE provides multiple (and potentially excessive) levels of oversight. It is recommended that before the RFP is issued, DOE define specifically the extent of oversight and the specific number of individuals from all organizations who would have "oversight" authority to ensure that DOE does not overwhelm the contractor with unnecessary involvement and requirements. It is key that DOE-ID and HQ oversight organizations, such as the Office of Environment, Safety, and Health (EH), and external organizations such as the Defense Nuclear Facility Safety Board, agree to this approach. 


\subsubsection{Occupational Safety and Health Administration (OSHA) Requirements}

OSHA most likely will not be the regulator for the nonradiological occupational safety and health aspect of a private sector facility located on the INEL. Section 4(b)(1) of the OSH Act provides:

Nothing in this chapter shall apply to working conditions of employees with respect to which other Federal agencies ... exercise statutory authority to prescribe or enforce standards or regulations affecting occupational safety or health.

In early 1974, the Atomic Energy Commission Chairman and the Labor Secretary exchanged correspondence in which Labor agreed that the AEC's (now DOE's) assertion of jurisdiction, pursuant to section 161(I)(3) of the Atomic Energy Act, regarding both radiological and nonradiological occupational safety and health standards "precludes the application of [the OSH Act] by operation of law under the terms of section 4(b)(I) of [the OSH Act] to the extent that the AEC issues safety and health standards and enforces those standards under its contractual authority pursuant to the AEC statute." Therefore, until this exemption is rescinded, DOE has exclusive authority to enforce occupational safety for this project.

\subsubsection{National Environmental Policy Act (NEPA)}

The INEL Environmental Restoration and Waste Management (ER\&WM) Environmental Impact Statement (EIS) provides an overall framework covering this activity. The applicable sections of the INEL ER\&WM EIS (referred to as the INEL EIS) related to alpha and TRU mixed wastes are contained in Volume 2 Part A, Section 3.1.3, and Volume 2 Part B, TRU-1. The INEL EIS does bound the transportation of TRU from other DOE facilities in the DOE complex to the INEL. Initial conclusions by the DOE Evaluation Team are that this project would require an EIS. The EIS could be brief and tier off of the existing INEL EIS.

The need for a tiered EIS is based on assuming a thermal treatment technology and that thermal treatment is analogous to incineration. 10 CFR 1021 Appendix $D$ to Subpart D lists classes of actions that normally require an EIS. Item D12 of this subpart states: "Siting, construction, and operation of incinerators....," indicates that an EIS would be required.

The tiered EIS should not be more than 150 pages, nor should it take more than 15 to 24 months to complete (i.e., attain a Record of Decision). The cost of the EIS should be $\$ 3 M$ or less. The majority of the information necessary to develop 
the tiered EIS is available from the INEL EIS. Technical information would be provided by the successful candidate.

10 CFR 1021 states that for "critical actions" the 500 year floodplain must be determined. It is assumed that this project meets the definition of a "critical action" as defined in that regulation. It is likely that the Mackay Dam failure probable maximum flood water depths, areal distribution, and velocities exceed those that would occur as a result of a 500 year flood of the Big Lost River. Therefore, one of the project requirements would be to use the probable maximum flood data for design and regulatory compliance requirements until a more formal 500 year flood plain map is completed in July 1996. When the new map is completed a determination should be made regarding the impacts of the new data on previous assumptions. This determination will not add to the cost of the EIS.

Based on current information, it does not appear that the RWMC is on a 500 year floodplain; plans are to recommend siting a private sector facility on or near the RWMC.

The NEPA compliance strategy for this project will require DOE-ID to obtain approval authority from DOE-HQ for the tiered EIS.

For purposes of NEPA planning, it is recommended that this project be phased. Phase I, the paper RCRA permitting phase, will be done under a categorical exclusion. Phase II of the project will involve private sector construction and financing of a treatment facility. Before major Federal funds can be committed for Phase II of the project, a Record of Decision on the tiered EIS must be issued. Phase II of the contract will be contingent on completion of the NEPA process.

\subsubsection{RCRA Permitting}

The problems and requirements associated with RCRA permitting of the facility are the same no matter where the facility is located. The permitting process could be completed in three to four years depending on how well the permit application is written. The RFP should require the contractor to obtain the RCRA permit.

Major concerns and questions relative to RCRA are:

1) EPA has a new draft combustion strategy which indicates volatile metals (lead and mercury) cannot be incinerated. Much of the TRUIALLMW contains these metals. This issue is being discussed at the DOE-HQ and EPA-HQ level. 
2) The required amount of characterization of the waste for "proper" $L D R$ treatment depends on how effective the treatment is (e.g., complete destruction of halogens). This issue needs to be discussed with the State of Idaho and can only be resolved if the treatment process can be proven to meet Destruction Rate Efficiencies for any waste placed in the treatment unit.

3) The State of Idaho must approve surrogate waste for test burns to prove treatment robustness. This issue needs further discussion with the State of Idaho.

4) A decision needs to be made prior to issuance of an RFP regarding who must sign the permit application. If DOE-ID has to co-sign the application, then treatment of off-site commercial waste is an issue which must be addressed and resolved.

\subsubsection{Toxic Substance Control Act (TSCA)}

There are approximately 7,600 containers of TRU and ALLMW which may contain PCBs at the RWMC. A TSCA Permit is required if the facility treats the $P C B$ contaminated waste. The RFP should require the contractor to obtain the TSCA permit.

The primary issue relative to TSCA is the regulations are not specific about siting a polychlorinated biphenyl disposal (treatment) unit in a floodplain. PCBs cannot be stored within a 100 year floodplain [40 CFR 761.65(b)(1)(v)]. EPA Region 10 indicated informally that they believe the floodplain prohibition also applies to incineration (thermal treatment) units. The 100 year floodplain has not been officially determined for the RWMC. As discussed above in the NEPA subsection, an evaluation is being conducted on previously developed information to determine if the RWMC is on a 100 year floodplain, or if more information is needed to make such a determination. The 100 year floodplain needs to be determined so the private sector can either build the facility above that floodplain elevation, or justify to the regulators that engineered barriers would preclude floodwater from reaching the treatment facility. This is not an insurmountable problem.

In the near future, DOE-ID intends to enter into negotiations with EPA Region 10 on the PCB storage; discussions on the potential of siting a thermal treatment process in the floodplain will be discussed then. To ever consider the conversion of the Pit 9 facility to a waste management operation, this issue must be addressed. 


\subsubsection{Clean Air Act}

At this time, indications from the State of Idaho are that all emissions from the facility would be considered part of the overall INEL emissions. There is a possibility that this issue is open for discussion with the State regulators. If not, the INEL M\&O, the private sector contractor, and DOE-ID would have to determine what the emissions are and agree on limits to avoid exceeding the INEL emissions limits.

\subsubsection{Clean Water Act}

There were no Clean Water Act issues identified.

\subsection{Public Participation and Involvement}

The three feasibility studies provided a broad range of public participation plans. The plans provided were consistent with the scope of work proposed by each contractor.

The public acceptance plans ranged from one that would use the INEL's Citizen Advisory Board and conduct the required public meetings, to another that has already begun the public participation process. Public meetings may be required in order to comply with the requirements of NEPA, RCRA, TSCA, Clean Air Act, and DOE Policy. There is an obvious opportunity to meet these public involvement requirements on a concurrent rather than a sequential basis. Such an approach would shorten approval times and most likely improve the probability of acceptance by the community.

One feasibility study recommended the INEL's traditional approach to public acceptance. That approach identifies the stakeholders and their issues and then educates them on the benefits of the proposed solution.

The thought in this approach seems to be that an educated public will accept the recommended solution, or at least see the local economic benefit. This approach has had only mixed success in the past for DOE.

SEG provided the most comprehensive public participation plan. This plan is already in progress. Seventeen stakeholders were identified. Meetings were conducted with them and primary and secondary issues for each stakeholder were included in the feasibility study. This participation plan includes stakeholder input in key technical decisions in advance of the minimum require public meetings.

Public involvement is required by:

- DOE Policy 
- $\quad$ NEPA, through its scoping meetings and public comment periods

- $\quad R C R A$, through its draft permit review.

'NEPA is DOE's responsibility if the facility is DOE regulated. If the facility were to be $N R C$ licensed, it is likely that DOE would need to act as a cooperating agency on the NEPA documentation with the NRC. In either case, DOE communication with the public before and during the NEPA process is imperative.

The private sector contractor (who signs the RCRA permit application) and the State of Idaho, are responsible for the public involvement process. The private sector contractor should not wait until issuance of the draft permit to begin a public involvement process. Coordination between DOE and the private sector on public meetings, public outreach, etc., must occur to ensure that the public is not imundated with separate meetings, documents, etc.

Should DOE decide to continue with the procurement of private sector treatment services for ALLMW and/or TRU waste, a comprehensive public participation plan similar to the $S E G$ plan described above should be required from the contractor. It is recognized that the public is generally opposed to incineration and that early involvement of the public to address their concerns is critical to successful waste treatment.

\subsection{Contractual, Business and Financial Terms}

\subsubsection{Contracting Strategies}

All three private sector (PS) firms were asked to provide a business plan which was to identify preferred and alternate contracting strategies. While three PS firms participated in feasibility studies, one offered two contracting strategies.

Therefore, there were four options for the DOE-ID Evaluation Team to consider. The options are the result of financing strategies and are graphically depicted in section 3.12 .3 below.

\subsubsection{Pre-Construction Contracting Strategy}

All four PS alternatives stated that DOE financial participation would be required during pre-construction licensing, permitting, design and development.

Three of the four PS options considered RCRA permitting to be at a significant enough risk level that they would require a cost type contract for this part of the effort. One PS option required minimal investment by 
DOE for permitting and licensing and two required milestone payments which indicates a firm fixed price contract with progress payments. Therefore, the studies indicate that DOE underwriting of the permitting process may be required.

The Business Subteam of the DOE-ID Evaluation Team believes that DOE would receive the greatest benefit from $P S$ services if a fixed price contract is negotiated for this phase of the process. It is believed that with a fixed price contract, costs would be better controlled, and the private sector would have an incentive to deliver quality products to the permitting agency.

\subsubsection{Construction Contracting Strategy}

All four of the recommended options stated that a firm fixed price contract would be appropriate for construction of needed capital assets and purchase of equipment. Two of the four considered recapturing capital investments of corporate funds with a fixed per unit price for treated waste payable by DOE during the operation phase of the contract. The other two requested progress payments during the construction cycle.

The cost of money associated with carrying unamortized construction costs into the operations phase is high. Therefore, DOE should consider the benefits of paying for construction costs when this phase of the contract and the process demonstration phase ends, but before operations begin. The principals of finance apply to this effort in the same way in which a home mortgage is amortized with heavy interest payments in the beginning of the finance period. Early payment would provide for significant cost savings.

\subsubsection{Operations Cycle Contracting Strategy}

All four PS options considered treatment to be based on a Fixed Price per Unit. All operating costs would be included in the Fixed Price per Unit for all four options. However, the two options which did not require DOE construction financing would include a portion of their Fixed Price per Unit to recover unamortized construction period costs, including the facility's capital cost of money.

Fixed unit pricing is considered desirable. 
3.12.1.4 Decontamination and Decommissioning (D\&D) Contracting Strategy

All four PS options stated that they would negotiate D\&D as part of a firm fixed price per unit, operating contract. One option stated that the uncertainties associated with disposal of the D\&D waste is so high that they would require DOE to accept and dispose of the resulting waste.

While costs vary greatly based on assumptions made by the $P S$ (greenfields $v$ s. non-greenfields $D \& D$ ), these studies recommend a fixed price contracting arrangement. The fixed price strategy shifts the risk of $D \& D$ to the PS and is considered desirable by the DOE-ID Evaluation Team.

\subsubsection{Business Strategies}

Some of the alternative business strategies were:

1) A private corporation with a specific charter and a life of at least 10 years with limited corporate liability:

2) A limited partnership where one general partner would have unlimited liability.

3) Teaming arrangements (generally considered a prime with subcontracts for subordinate team members)

Generally, the form of business proposed does not offer specific advantages or disadvantages to DOE, nor do they affect the indemnification of DOE for this project. However, the contract needs to be clear that the parent corporation(s) will assure performance of the subsidiary's obligations under the contract.

\subsubsection{Financing Strategies}

A financing strategy was to be provided and identify the source(s) of funds required prior to and during operation. Any contractual guarantees required by DOE-ID to secure the required financing were to be identified.

The contracting arrangements for the four activities that were proposed are indicated in Table 3-1. The contracting arrangements drive the financing. 
Table 3-1. Contracting arrangements

\begin{tabular}{||l|l|l|l|l|}
\hline \hline Option & Licensing & Construction & Operations & \multicolumn{1}{|c|}{ D\&D } \\
\hline 1. & CPFF & FPU & FPU & FPU \\
\hline 2. & CPI & FFP(PP) & FPU & FFP \\
\hline 3. & CPIF & FPU & FPU & FFP \\
\hline 4. & FFP(PP) & FFP(PP) & FPU & FFP \\
\hline
\end{tabular}

CPFF $=$ Cost Plus Fixed Fee

$\mathrm{CPIF}=$ Cost Plus Incentive Fee

FPU = Fixed Fee Per Unit of Treated Waste

FFP $=$ Firm Fixed Price

(PP) $=$ Progress Payments Required

\subsubsection{Terms and Conditions ( $\mathrm{T} \& \mathrm{C}$ )}

Terms and conditions recommended by the PS are voluminous. This section of the report will deal with samples of interest of recommended terms and conditions (T\&C), as many are relevant to all three feasibility studies.

- DOE agrees to pay for all costs associated with future revisions to final waste acceptance criteria which is not controlled by the contractor.

- The contractors require a guaranteed minimum total quantity of waste and a guaranteed minimum annual quantity of waste for processing. They did not address DOE's obligation to them for not meeting the guaranteed minimum.

- In the event the contractor cannot obtain the required permits within five years of application, they want the contract terminated without fault.

- In the event DOE terminates for convenience, the contractor's reasonable out-of-pocket costs will be paid.

- Cumulative liability under the contract would be limited to the value of the contract.

- In recognition of the risks undertaken by contractor, they request that a future determination of the above normal profits not be a basis for renegotiation of price. 
- With DOE as the sole customer, the contractor assumes that waste generated at the facility and D\&D waste can be disposed at a DOE facility with no disposal cost to the contractor.

- Contractor recommends separate contracts for different phases of work. For example, the high risk license and permit phase could be covered in a cost plus fixed fee contract, whereas the construction and operations phases are covered by a fixed price/unit contract.

While most terms and conditions provided in the studies were useful, the team found that some recommended clauses are either contrary to procurement regulations or are not in the best interest of the Government. See Section 5 of this report for an expanded discussion on recommended terms and conditions.

\subsubsection{Private Sector Approach to Other Markets and Pricing Strategies}

\subsubsection{Other Markets - TRU Treatment}

All PS study contractors stated that they would treat INEL TRU waste to LDR and indicated they would treat all contact handled TRU at the marginal prices presented in the feasibility studies. Treatment of TRU to LDR would meet the WIPP WAC. The price for the treatment of TRU is discussed in detail in Section 3.13.2 of this report.

Only one study stated that they would consider treating TRU to the WIPP WAC; they estimated an additional $\$ 20 \mathrm{M}$ would be required for capital investment. They did not estimate the operating costs associated with WIPP WAC treatment of TRU.

\subsubsection{Pricing}

Two basic approaches to pricing strategies were presented in the feasibility studies. One was based on private sector financing with limited DOE financial participation prior to facility start-up. The other pricing strategy was based on DOE milestone payments prior to operation.

The pricing strategy based on private financing was assessed via investment analysis. To perform investment analysis, all related costs of the firm under observation were analyzed. Analysis of total cost is important to investment analysis, because private business cannot charge certain expenses to the Government as they are unallowable per regulation (e.g., interest expense, Federal income tax expense). Nevertheless, these are real 
costs to the contractor and must be included in the assessment of business alternatives.

The investment analysis required calculation of the unit price that produced a yield consistent with the pricing strategy, net of original capital investment, taxes, and other real but nonreimbursable costs. This pricing strategy incorporates an after-tax present value analysis using "real" (net of inflation) FY-94 dollars.

The pricing strategy, based on DOE milestone payments prior to operation, calculated unit prices by dividing total cost by total annual volume. With differences between planned and recommended scheduling attributes, adjustments to recommended schedules were made. Total cost was determined by summing the total annual costs including contingency, then adding a percentage of that amount as "fee" or "profit".

The imputed after-tax rates of return on investment, as well as the percentage of fee/profit presented in the feasibility studies, were evaluated and deemed to be reasonable. Each study provided for volume price breaks that reduce the marginal unit price based on recovering capital investment over a specified quantity of waste. The unit prices in Table 3-2 below include the volume price breaks described in the studies. The unit price for treating the ALLMW and TRU waste in the IWPF is shown for comparison. It should be noted that the IWPF unit price does not treat all of the waste to LDR standards while the PS treatment does. The private sector did not provide estimates for treating TRU to the WIPP WAC.

Table 3-2. Unit Prices for Treating ALLMW and TRU.

\begin{tabular}{|l|c|c|c|}
\hline $\begin{array}{l}\text { Cost per cubic } \\
\text { meter in FY-94 \$s } \\
\text { Treatment Only }\end{array}$ & $\begin{array}{c}\text { ALLMW Only to } \\
\text { LDR }\end{array}$ & $\begin{array}{c}\text { ALLMW + TRU } \\
\text { to } \\
\text { LDR }\end{array}$ & $\begin{array}{c}\text { ALLMW to LDR and } \\
\text { TRU to WIPP WAC }\end{array}$ \\
\hline Private & $\$ 8,900-\$ 13,900$ & $\$ 3,700-\$ 6,300$ & N/A \\
\hline IWPF & $\$ 16,000$ & N/A & $\$ 9,600$ \\
\hline
\end{tabular}

The private sector unit prices are based on INEL $M \& O$ retrieval and assay schedules before treatment. As discussed in the Cost Evaluation Section (3.13), these costs can be further reduced by providing the waste for treatment more rapidly. The unit costs presented are rounded to the nearest $\$ 100$ and include an allowance for INEL NEPA and program monitoring. 
The potential savings for using the private sector and the economies of scale in treating all of the stored waste to the LDR standard are apparent.

\subsection{Cost Evaluation of Feasibility Studies}

All three feasibility studies were responsive to the SOW requirements for cost estimates and pricing strategies. Two of the studies provided multiple alternatives for consideration. In these instances, the alternative judged most responsive to DOE's needs was selected for inclusion in this report. All costs are reported in constant FY-94 dollars. All three studies presented life cycle costs from design through D\&D of the facility.

The SOW for the feasibility studies required the contractors to provide the costs and the prices they would charge DOE for their services. Some contractors included their "fee" in the cost analysis and others included their "profit" in a price. In this cost comparison, cost is defined as the total amount paid by DOE for treatment service.

\subsubsection{ALLMWCost Evaluation}

The minimum scope of work for the feasibility studies was the treatment of INEL's ALLMW to meet Land Disposal Restrictions (LDR) and satisfy DOE performance assessment requirements for disposal. For comparison, the ALLMW treatment costs provided in the feasibility studies were adjusted for three reasons: Escalation, Waste Quantity and Treatment Schedule.

Where escalated dollar amounts were provided in a feasibility study, they were de-escalated to allow a comparison in constant FY-94 dollars. The escalation rates provided by the contractor in each feasibility study were used for these calculations.

All three studies claim to be able to treat all of the INEL's ALLMW. Two of the studies based their estimates on the total quantity of ALLMW identified in the waste description document provided to them. To be conservative, the third study based its estimate on less than $100 \%$ of ALLMW. The operating life of the facility was extended for the third study to allow all three feasibility studies to be compared on the basis of an equal quantity of waste treated. The cost of this extension was calculated based on the operating costs and fees provided by the contractor.

The final reason for adjusting the costs provided in the feasibility studies concerns the treatment schedules recommended in the studies. Two of those schedules assumed the waste would be available for treatment far more rapidly than currently included in INEL plans and permits. The INEL estimate to accelerate retrieval was developed in 1993 for the "Operational Implementation 
Plan for Commercial Treatment of Alpha-LLW." The estimate to accelerate retrieval, \$286M plus contingency, is not feasible based on the high costs. Instead, the treatment schedules presented in the feasibility studies were modified to treat the waste as it becomes available from the planned retrieval process. This modification extended the operating life of each facility and necessitated adjustments to the estimated costs. During the extended operating life, the fee percentage was maintained for those studies that included fee as a cost, and the real after-tax rate of return on investment was maintained on a net present value basis for those studies that included profit in the price of the treatment service.

Based on the adjusted feasibility studies, DOE's cost to treat the ALLMW to LDR ranges from $\$ 195$ to $\$ 305 M$ with completion between years 2011 and 2012. This result assumes that the INEL's SWEPP facility can assay waste at the same rate as the INEL's retrieval process makes waste available for assay. At the currently planned operating level for SWEPP, the private sector treatment facilities would be extended to complete treatment between years 2014 and 2016, with the cost to $D O E$ increasing to a range of $\$ 230 \mathrm{M}$ to $\$ 360 \mathrm{M}$. Both of the ranges for private sector treatment costs include approximately \$10M in internal INEL costs associated with program management infrastructure improvements and NEPA. The private sector cost ranges can be compared to the $\$ 413 M$ estimate to treat the ALLMW to LDR using IWPF. That project would complete treatment in year 2017, assuming a start-up in year 2010.

\subsubsection{TRUCost Evaluation}

Each of the three feasibility studies addressed the potential of treating TRU waste to the same LDR standards proposed for the ALLMW. Although LDR treatment of TRU waste is not required, it exceeds the requirements of the current WIPP WAC. The current DOE strategy is to treat or repackage TRU waste only as necessary to meet the WIPP WAC. One of the feasibility studies estimated the cost of treating TRU and ALLMW to different standards, and the cost of treating all waste to the LDR standard. That study estimated that in comparison to treating all waste to $L D R$, an additional \$20M capital cost and an undetermined increase in annual operating costs would be required to treat TRU waste to the WIPP WAC. The cost of treating the two waste types to different standards exceeds the cost of treating both waste types to the higher LDR standard.

The recommended facilities accommodate the increased quantity of waste by either an extended operating life or an increased annual capacity. Two studies extend the operating life and the third study operates the recommended facility at its annual design capacity rather than the reduced capacity recommended to treat only the ALLMW quantity of waste. The cost adjustments previously described for $A L L M W$ are also applicable to the combined TRU and ALLMW scenarios 
presented in the remainder of this report section. The costs presented include quantity price breaks as described in the feasibility studies.

Based on the adjusted feasibility studies, DOE's cost to treat the INEL's stored TRU and ALLMW to LDR ranges from $\$ 225 M$ to $\$ 340 M$, with completion between years 2012 and 2013. This result assumes that the waste can be made available for treatment at the INEL's planned retrieval rate. If the availability for treatment is constrained by the planned operating level for SWEPP, the private sector treatment facilities would be extended to complete treatment between years 2014 and 2016 with the cost to DOE increasing to a range of $\$ 240 \mathrm{M}$ to $\$ 395 \mathrm{M}$.

Both of the ranges for private sector treatment costs include approximately $\$ 15 M$ in internal INEL costs associated with program management and NEPA. The private sector cost ranges can be compared to the IWPF \$620M estimate to treat the ALLMW to the LDR standard and the TRU waste to meet the WIPP WAC (see Table 3.). That project would complete treatment of ALLMW and TRU in 2020, assuming a start-up in year 2010. All waste would be disposed at. WIPP by 2021.

One purpose for conducting the feasibility study was to develop a DOE estimate that could be used to budget for a future procurement of waste treatment services from the private sector. To develop a confident budget estimate similar cost elements (e.g., $D \& D$ estimates) and the varying contingency rates were compared among the feasibility studies. A separate allowance for "special contingency" was included in recognition of the early stage of this procurement plan. The budget estimate to treat the INEL's stored ALLMW and TRU waste to $L D R$ standards using the private sector for treatment services is $\$ 405 M$. 
Table 3-3. Treatment Cost Comparisons (FY-94 millions).

\begin{tabular}{||c|c|c|c|c||}
\hline \multirow{2}{*}{} & \multicolumn{2}{|c|}{ ALLMW } & \multicolumn{2}{c||}{ ALLMW and TRU } \\
\cline { 2 - 5 } & COST & SCHEDULE* & COST & SCHEDULE* \\
\hline Feasibility Studies & & & & \\
\hline - Available when retrieved & $\$ 195-305$ & $2011-2012$ & $\$ 225-340$ & $2012-2013$ \\
\hline $\begin{array}{c}\text { - Available when assayed by } \\
\text { SWEPP }\end{array}$ & $\$ 230-360$ & $2014-2016$ & $\$ 240-395$ & $2014-2016$ \\
\hline - Budget Estimates & $\$ 413$ & 2017 & $\$ 620$ & 2020 \\
\hline IWPF ** & & & $\$ 405$ & 2016 \\
\hline
\end{tabular}

* Dates shown are the year treatment would be complete. Additional time is required to transport waste to the disposal site.

** Assumes a 2010 start-up date. TRU waste is treated to meet the WIPP WAC in IWPF.

\subsection{3 'Overall INEL Cost Evaluation}

The overall cost impact of private sector treatment of ALLMW and TRU waste on the INEL TRU waste program is much greater than a comparison of treatment costs alone. The overall impact must take into account the interdependencies between the treatment process and the other processes related to the stored waste. The major related processes include retrieval, storage, assay, characterization 'and transportation to a disposal facility. As an optional scope of work, one of the feasibility studies estimated the cost of private sector waste retrieval. If required in a future services contract, it is assumed that all respondents could provide retrieval services at comparable costs.

With the private sector treatment schedules, the requirements for $R C R A$ compliant storage buildings are significantly reduced in comparison to the baseline INEL plan. All three studies include assay and characterization activities that may duplicate planned INEL activities. Following LDR treatment, the total quantity of waste transported to WIPP is reduced; however, the anmual shipment rate is higher and the arriving TRUPACT IIs cannot be fully loaded (only 8 drums can be shipped per TRUPACT II vs. the normal 14; drums can only be filled $2 / 3$ full due to weight/density). Finally, the maintenance, utility and supporting programmatic and "hotel" costs associated with these major processes terminate earlier in the private sector scenarios than in the INEL baseline plan.

To evaluate the complexity of the possible alternatives, a systems analysis approach was used to develop a computer simulation model. The model 


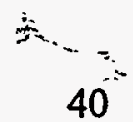

correlates each physical process with the estimated cost for that process. The physical processes are modeled with variables such as start dates, capacities, volume reduction, number of operating shifts and anticipated waste characteristics. (e:g., number of retrieved boxes and drums, fraction of waste that will assay as ALLMW, fraction of TRU drums that will meet the WIPP WAC without repackaging, etc.). The cost estimates in the model were obtained from the feasibility studies, INEL estimates for Line Item Construction Projects, and a projection of all TRU related control accounts for the INEL. Utility, maintenance and other costs that could not be directly attributed to one of the major processes were allocated to either "storage" or "examination" based on the algorithm approved by the INEL TRU Waste Type Manager. The model calculated the physical flows and associated costs on a quarterly basis.

The model was run for each alternative of interest for the time period of 1995 to completion. Completion was defined as all waste from the INEL being disposed at WIPP. The results are shown in Table 3-4. The first column represents the current INEL baseline plan, which is to treat the ALLMW to LDR standards and to repackage the TRU waste to meet the WIPP WAC in the IWPF. The second column displays the ranges of results of three "private sector treatment only" alternatives. In those scenarios the INEL retrieves, assays and characterizes (termed "examination" in the table) as planned with the three feasibility study treatment plans substituted for IWPF treatment. All waste is treated to LDR requirements. The third column displays the ranges of results of three "private sector turn-key" alternatives. One of these alternatives substitutes private sector retrieval for INEL retrieval. All three eliminate INEL assay and characterization activities if the facility is located on site.

In comparison to the current INEL baseline plan, the budget estimate for private sector treatment of ALLMW and TRU waste to LDR standards could save approximately $\$ 404 \mathrm{M}$. In the process, a smaller volume of waste would be disposed at WTPP five to seven years earlier than currently planned. Using private sector retrieval, assay and characterization services could increase total $D O E$ savings to $\$ 820 M$ and dispose of the waste seven to eight years earlier than currently planned.

Additional savings could be realized by optimizing the TRU transport system for treated waste. The current system was designed for untreated waste. The waste form expected after treatment would be much denser and more durable than untreated waste. It would perform better under accident scenarios; however, the current weight restrictions would not allow full use of the available transport capacity. The number of shipments to WIPP could be significantly reduced with a transport system designed specifically for treated waste. DOE-ID plans to 
request that the TRU transport system be re-evaluated by the Carlsbad Area Office to determine if additional life-cycle cost savings can be achieved.

Table 3-4. Alternative Plans for TRU and Alpha Contaminated Waste.

\begin{tabular}{|c|c|c|c|}
\hline $\begin{array}{l}\text { Constanit FY-94 Dollars In } \\
\text { (Mintions) }\end{array}$ & $\begin{array}{l}\text { Current Plan } \\
\text { INEL Retrieval, } \\
\text { Examination and } \\
\text { Treatment }\end{array}$ & $\begin{array}{l}\text { INEL Retrieval and } \\
\text { Examination With } \\
\text { Private Treatment } \\
\text { (All to LDR) }\end{array}$ & $\begin{array}{c}\text { NEL Private Retrieval } \\
\text { Examination \& } \\
\text { Treatment } \\
\text { (All to LDR) }\end{array}$ \\
\hline Retrieval & $\$ 70$ & $\$ 70$ & $\$ 20-\$ 70$ \\
\hline Examination & $\$ 512$ & $\$ 400-\$ 420$ & $\$ 150-155$ \\
\hline Storage & $\$ 321$ & $\$ 260-\$ 270$ & $\$ 200-\$ 255$ \\
\hline Treatment & $\$ 620$ & $\$ 240-\$ 395$ & $\$ 225-\$ 340$ \\
\hline Transportation & $\$ 124$ & $\$ 65-\$ 100$ & $\$ 65-\$ 100$ \\
\hline Total INEL Cost & $\$ 1,647$ & $\$ 1,035-\$ 1,255$ & $\$ 745-\$ 920$ \\
\hline INEL Budget Estimate & $\$ 1,647$ & $\$ 1,243$ & $\$ 827$ \\
\hline Disposal Date & 2021 & $2014-2016$ & 2013-2014 \\
\hline $\begin{array}{l}\text { Resulting Volume from } \\
\text { Treatment to WIPP WAC } \\
\left(\mathrm{m}^{3}\right) \times 1,000\end{array}$ & 30 & 0 & 0 \\
\hline $\begin{array}{l}\text { Resulting Volume from } \\
\text { Treatment to } \operatorname{LDR}\left(\mathrm{m}^{3}\right) \times \\
1,000\end{array}$ & 8 & $17-27$ & $17-27$ \\
\hline $\begin{array}{l}\text { Total Volume }\left(\mathrm{m}^{3}\right) \mathrm{x} \\
1,000\end{array}$ & 38 & $17-27$ & $17-27$ \\
\hline
\end{tabular}

\subsection{DOE-ID Decision Making Process}

In order to evaluate the potential benefit of procuring treatment services from the private sector, DOE-ID assembled an internal, multi-disciplinary team consisting of approximately twenty seven individuals. These individuals participated in the evaluation of the feasibility studies and in the decision making process (see Appendix A for team member names). Team members had extensive knowledge in all relevant areas: current INEL mixed waste management strategies, regulatory statutes, environmental technologies, public involvement/acceptance, transportation, business and finance, legal, health and radiation safety, and site labor agreements.

The decision making process regarding private sector treatment services involved two phases. Strategic issues were addressed first, followed by tactical issues. 
The strategic phase of the process involved identifying the optimal scope of work for privatization. This entailed defining goals and objectives then formulating candidate alternatives; these candidate alternatives were evaluated with respect to the objectives to develop feasible alternatives.

After developing feasible alternatives, the team focused on tactical issues, that is, how should DOE-ID execute the scope of work (i.e., who, when, where). This phase encompassed formulating candidate options (i.e., subsets of feasible alternatives from the strategic phase), then evaluating candidate options against the original objectives. From this analysis, a path forward was defined and recommendations were provided to Senior DOE Management.

Throughout the decision making process, awareness of private sector ideas and strategies gleaned from the feasibility studies proved extremely valuable to the team.

\section{Strategic Phase}

1) Define Goals and Objectives

2) Formulate Feasible Alternatives with Respect to Objectives

\section{Tactical Phase}

1) Formulate Options (subsets of feasible alternatives)

2) Evaluate Options with Respect to Objectives

3) Define the Path Forward for Senior DOE Management

\subsection{Definition of Goals and Objectives}

The following goal statement was formulated and agreed upon by the team:

\section{"Dispose of INEL Mixed Waste in a Safe and Permanent Manner"}

The goal statement provided focus for the team throughout the decision making process. Although the initial scope of the privatization initiative was INEL ALLMW, the goal statement was not restricted to ALLMW. The team did not want to preclude other forms of mixed waste (i.e., TRU) from a strategy for final disposition.

The team defined three objectives that support the goal:

1) Demonstrate progress to the State of Idaho on treatment and disposal of ALLMW

2) Minimize cost with respect to risk sensitivities 
3) Accomplish the goal in a safe, ethical, and legal manner.

These objectives were used in the strategic and tactical phases to evaluate candidate alternatives and subsequent options (of feasible alternatives). Figure 4-1 illustrates the sequence and outcome of decision making process. Explanation of the rationale for alternative and options selection/rejection follows.

\section{Strategic}

\section{$\underline{\text { Tactical }}$}

1. Non-Treatment Alternatives

A. No Action/Minimal Action

1) Do Nothing

2) Barrier Enhancement

3) RE Building

4) RE Building and Barrier Enhancement

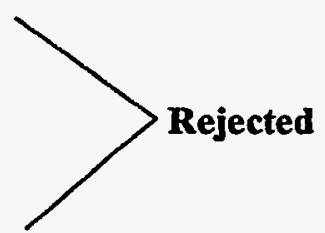

B. Retrieval \& Indefinite RCRA Compliant Storage

2. Treatment Altematives

Options for Feasible Alternative

A. M\&O IWPF Concept (alpha to LDR \& TRU to WIPP WAC) Rejected

B. Private Sector Concept (treat alpha and TRU to LDR)

\begin{tabular}{l|l}
\hline WAC) Rejected & Rejected \\
\hline & \begin{tabular}{|l} 
Sole Source \\
Private Sector Turakey
\end{tabular} \\
\hline $\begin{array}{l}\text { Privale Setor Treatment w/ } \\
\text { M\&O Retrieval } \\
\text { M\&O Treatment }\end{array}$ & Selected \\
\hline
\end{tabular}

Figure 4-1. Overview of Decision Making Process

\subsection{Strategic Phase}

\subsubsection{Formulate Feasible Alternatives}

The team developed two sets of alternatives (non-treatment and treatment). Figure 4-2 illustrates the setup of the strategic phase of the decision making process. Candidate alternatives are briefly described below. Note that for this stage, the team took a much broader view of potential actions. Due to actual and anticipated DOE budget cuts, the team wanted to evaluate "no action" types of alternatives to see if there would be cost savings, without any increased risk to the environment. 
A. Non-Treatment Alternatives:

1) No Action - leave waste in berm

2). Barrier Enhancement - construct a protective cap over the bermed: waste to prevent infiltration and subsequent waste migration

3) Retrieval Enclosure (RE) Building - enclose the berm in a protective building for indefinite storage

4) Retrieval Enclosure (RE) Building and Barrier

Enhancement - a combination of alternatives $2 \& 3$

5) Retrieval of all Alpha and TRU Mixed Waste and "Indefinite" RCRA Compliant Storage - retrieve all drums and boxes of ALLMW. and mixed TRU waste, repackage as necessary, and store in Type II storage buildings for 55 years

B. Treatment Alternatives:

1) M\&O IWPE Concept - retrieve all waste, sort, treat ALLMW to LDR, land dispose of alpha low level waste, treat TRU to WIPP WAC, ship TRU to WIPP

2) Private Sector Concept - retrieve all waste, treat ALLMW and TRU waste together to LDR, and ship resulting TRU waste to WIPP 


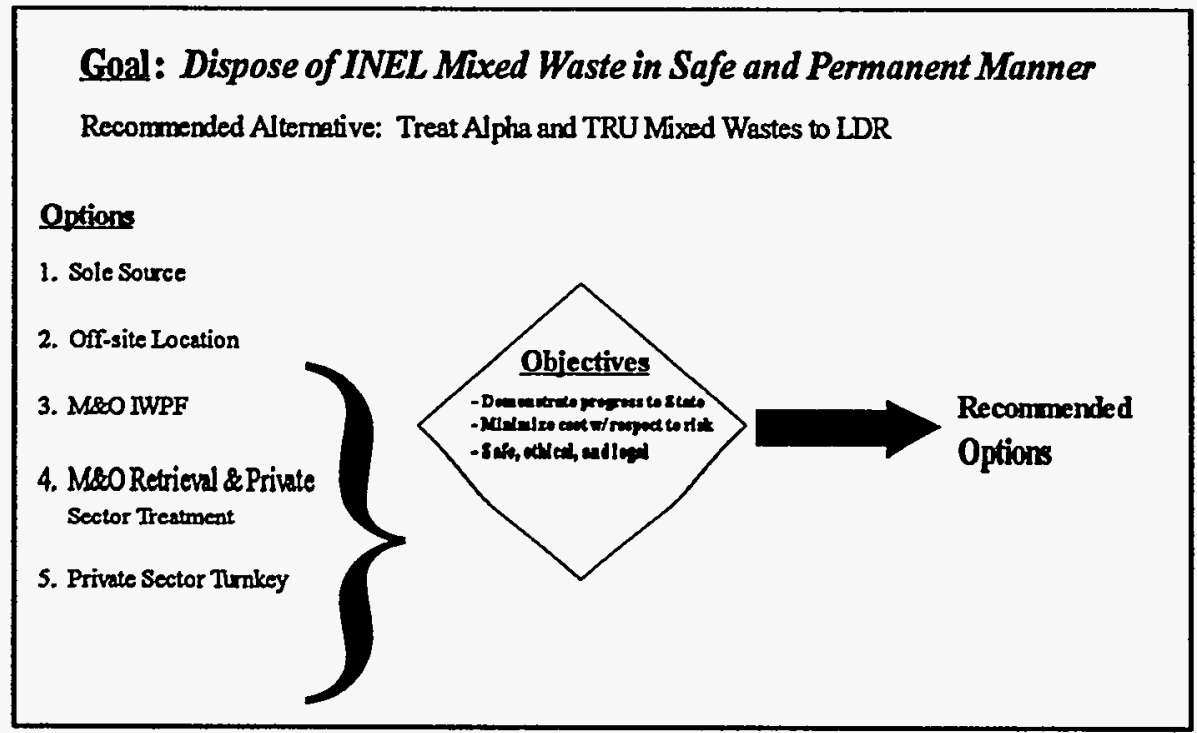

Figure 4-2. Overview of Tactical Phase of Decision Making Process.

To identify feasible alternatives, candidate treatment and non-treatment alternatives were evaluated against the objectives. By consensus decision the team : rejected all non-treatment alternatives. Non-treatment alternatives A.1, A.2, A.3, and A.4 were rejected due to the lack of demonstrable progress to the State and on legal and ethical grounds. From an ethics perspective, the team agreed that continued storage of bermed waste could result in further deterioration in container integrity increasing the potential for contaminant migration into the Snake River aquifer and potential adverse consequences for future generations. Costs associated with the barrier enhancement alternatives (A.2) were not estimated, but construction costs would probably range from $\$ 10$ million $-\$ 20$ million with additional costs for continuous monitoring. Costs for construction of the Retrieval/Enclosure (RE) Building (Alternative A.3) over the bermed waste, personnel costs, and monitoring for 55 years was estimated to be $\$ 1.1$ billion. A combination of the RE building and a construction of a earthen barrier would be slightly more than $\$ 1.1$ billion.

Alternative A.5 (Retrieval of all Mixed Waste and Indefinite RCRA Compliant Storage) was also rejected. Although Alternative A.5 removes the waste from the berm and would thereby demonstrate progress to the State, the risk of migration and exposure is not significantly reduced, i.e., potential for migration and exposure via natural disasters over the 55 year time frame. Furthermore, the estimated cost to DOE for this alternative is $\$ 1.4$ billion over 55 years (RWMC storage costs, personnel, monitoring, etc.).

Next, the two candidate treatment alternatives were evaluated. The first alternative was the baseline INEL M\&O plan, the IWPF. This concept entails 
M\&O retrieval of all bermed waste over the next 15 years, segregating the waste (alpha and TRU) based on radiological assay, treating ALLMW to LDR, treating TRU to WIPP WAC, and shipping all TRU to WIPP. Figure 4-3 illustrates the process flow for this alternative.

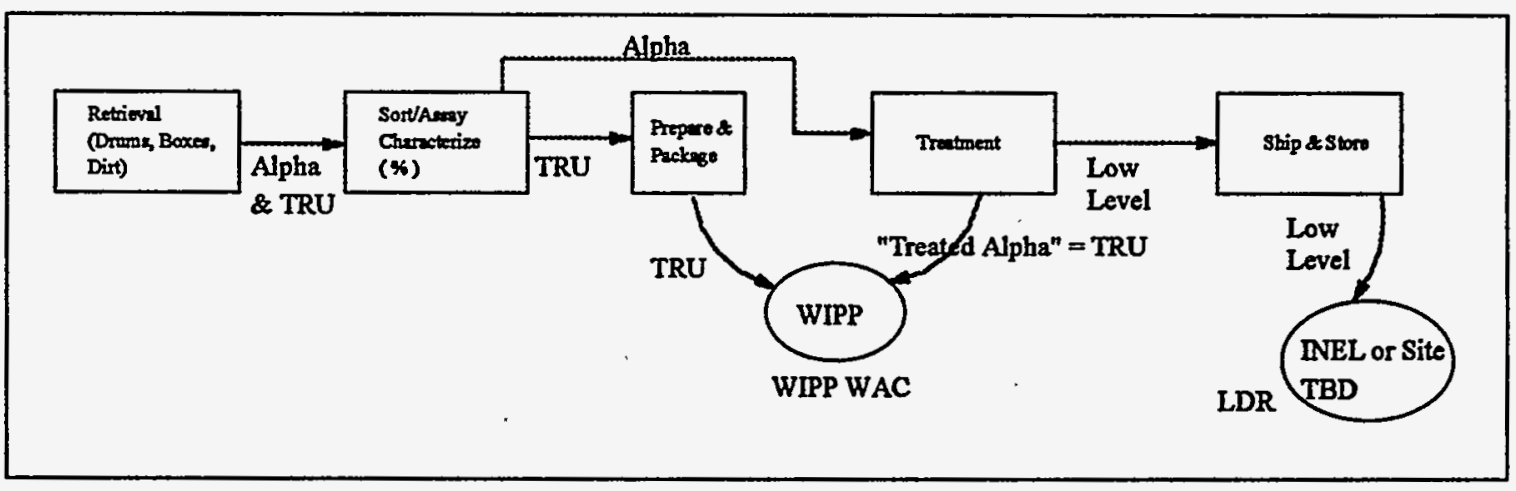

Figure 4-3. Baseline M\&O IWPF Concept: Treat Alpha and TRU Separately

The alternative of treating alpha and TRU separately was comprised of two variations: 1) $M \& O$ retrieval and $M \& O$ treatment of ALLMW to LDR or 2) M\&O retrieval and equivalent private sector treatment.. The second treatment alternative was a.concept recommended in all three private sector feasibility studies, i.e., treat all waste together to LDR (treatment renders all waste to TRU) and ship TRU to WIPP. This alternative was also comprised of two variations: 1) M\&O retrieval and private sector treatment or 2) private sector retrieval and private sector treatment. Figure 4-4 illustrates the process flow for this alternative. Again, these steps are similar with or without private sector involvement.

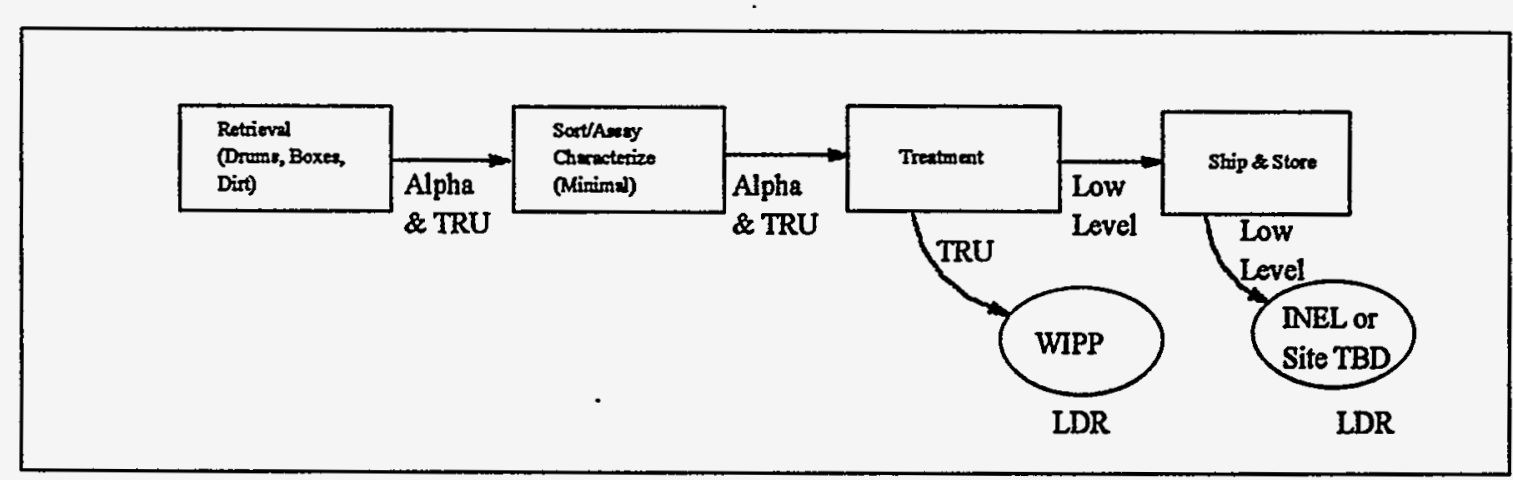

Figure 4-4. Private Sector Concept: Treat Alpha and TRU Together 


\subsubsection{Evaluate Feasible Alternatives with Respect to Objectives}

The following discussion highlights and qualifies comparison of alternatives relative to each objective. Table 4-1 summarizes treatment alternatives with respect to the stated objectives. Life-cycle costs (retrieval, storage, assay, characterization, treatment, and transportation to WIPP) are used.

Table 4-1. Treatment Alternatives with Respect to Objectives.

\begin{tabular}{|c|c|c|c|}
\hline $\begin{array}{l}\text { Treatment } \\
\text { Alternative }\end{array}$ & $\begin{array}{l}\text { Demonstrate } \\
\text { Progress to State }\end{array}$ & $\begin{array}{l}\text { Minimize Cost w/ } \\
\text { Respect to Risk* }\end{array}$ & $\begin{array}{l}\text { Safe, Legal, and } \\
\text { Ethical Conduct }\end{array}$ \\
\hline $\begin{array}{l}\text { M\&O IWPF Concept } \\
\text { (M\&O retrieval \& treat } \\
\text { alpha \& TRU separately) }\end{array}$ & $\begin{array}{l}\text { TRU to WIPP by } 2021^{* *} \\
\text { Alpha disposal site TBD }\end{array}$ & $\$ 1.6$ billion & \\
\hline $\begin{array}{l}\text { Private Sector (treat } \\
\text { alpha only) Concept } \\
\text { (M\&O retrieval \& treat } \\
\text { alpha \& TRU separately) }\end{array}$ & TRU to WIPP by 2016 & $\$ 1.2$ billion & \\
\hline $\begin{array}{l}\text { Private Sector Treat-all } \\
\text { Concept (treat alpha \& } \\
\text { TRU together to LDR) w/ } \\
\text { M\&O Retrieval }\end{array}$ & $\begin{array}{l}\text { Alpha \& TRU waste to } \\
\text { WIPP by } 2016 \\
\text { Most waste out of Idaho }\end{array}$ & $\$ 1.2$ billion & $\begin{array}{l}\text { - Reduced handling \& } \\
\text { exposure for workers } \\
\text { - Increased criticality } \\
\text { concerns }\end{array}$ \\
\hline $\begin{array}{l}\text { Private Sector Treat-all } \\
\text { Concept (treat alpha \& } \\
\text { TRU together to IDR) w/ } \\
\text { Private Sector Retrieval }\end{array}$ & $\begin{array}{l}\text { Alpha \& TRU waste to } \\
\text { WIPP by } 2013 \\
\text { Most waste out of Idaho }\end{array}$ & $\$ 827$ million & $\begin{array}{l}\text { - Reduced handling \& } \\
\text { exposure for workers } \\
\text { - Increased criticality } \\
\text { concerns }\end{array}$ \\
\hline
\end{tabular}

* Total DOE/INEL life-cycle costs

** Based on operations beginning in 2010; this does not support current WIPP closing date of 2018

\section{Objective 1: Demonstrate Progress to State}

All four alternatives demonstrate DOE commitment to retrieving, treating, and disposing of mixed waste. The primary discriminators are: 1) time required to complete retrieval, treatment, and disposal, and 2) the final location for disposition of LDR treated ALLMW.

M\&O IWPF Concept - For the baseline alternative, where all work is performed by the M\&O, it is estimated that all TRU waste will be shipped to WIPP by 2021 (assuming IWPF begins treatment by 2010). If there is any remaining alpha low level (waste that does not include a hazardous waste constituent), it can be land disposed (shallow burial) at INEL or a location to be determined. For the private 
sector treatment alternative, shipment of TRU waste to WIPP is completed by 2016. Similarly, remaining alpha low level waste is land disposed. It is estimated that use of private sector treatment services will reduce the baseline IWPF schedule by four to seven years.

Private Sector Concept - Treating alpha and TRU waste streams together creates significant process efficiencies in sorting, assaying, and characterizing wastes. However, many of these efficiencies are lost due to the M\&O's planned retrieval rate which is lower than the private sector's recommended treatment capacity; this translates into increased time and costs for the private sector and DOE. As a result, waste shipments to WIPP are completed by 2016. This alternative removes nearly all TRU contaminated waste from the State of Idaho since all treated alpha becomes TRU waste and is sent to WIPP. Private sector treatment of alpha and TRU waste streams together, combined with private sector retrieval, would allow the private sector to increase the retrieval schedule, thereby increasing system efficiency. For this alternative, it is estimated that most all mixed TRU and alpha waste would be removed from Idaho and sent to WIPP by 2013. It is estimated that a private sector "turn-key" operation will reduce the baseline IWPF schedule by seven to eight years.

\section{Objective 2: Minimize Cost with Respect to Risk Sensitivities}

There is a wide range of costs between treatment alternatives. Total DOE/INEL life-cycle costs are presented in Table 4-1. Looking strictly at costs, the difference between the M\&O IWPF concept of treating waste streams separately and the private sector concept of treating alpha and TRU together, is approximately $\$ 800$ million ( $\$ 1.6$ billion and $\$ 827$ million, respectively). However, in addition to bottom line costs, treating all waste together generates other risk reduction benefits for DOE.

1) The amount of assay and characterization required is greatly reduced when all waste is treated to LDR. In order to segregate alpha and TRU waste, assay capabilities must be very precise, particularly for waste readings approaching the classification limits. This degree of assay precision requires more time and effort. In contrast, treating alpha and TRU waste together requires only a safety assay for maintaining criticality control. Similarly, the amount of characterization required to treat alpha and TRU separately, versus together, differs markedly. Much less characterization is required for a homogenous treatment product. Differences in the amount of assay and characterization required for treating alpha and TRU waste together result in significant time and cost savings. 
2) The utility of a consistent and stable final waste form improves system efficiency and safety in transportation, handling, and storage.

3) Volume reduction from treating all waste is significant, reducing transportation costs, transportation safety-related issues, and perhaps WIPP operational costs (not calculated). Potential WIPP cost reductions were not calculated.

4) All waste is treated, volume reduced, and becomes TRU, eliminating the need for separate land disposal of alpha low level waste.

Treating alpha and TRU wastes together should result in significant cost savings as well as lessen some of the fundamental risks and uncertainties facing DOE in dealing with mixed waste.

\section{Objective 3: Accomplish the Goal in a Safe, Ethical, and Legal Manner}

The primary discriminators in the comparison of the two base alternatives (treating alpha and TRU separately or together) involved worker safety and criticality controls. The evaluation team believed that treating all waste streams together and using private sector assay and characterization would greatly decrease worker exposure to radiation and hazardous waste. On the other hand, the team felt treating all wastes together would increase criticality concerns; however, the team's radiation experts believed these concerns could be adequately addressed through treatment process controls. Regulatory experts indicated that obtaining a RCRA Part B permit would be similar with either alternative, although it was recognized that the "Treat-all" concept would entail significantly more thermal treatment which is a sensitive issue, given the public's negative attitude towards incineration-like-treatment. Significantly fewer shipments to WIPP, and a more stable and known waste form, enhances public safety. In summary, treating all wastes to LDR should decrease risks to workers and the public assuming adequate worker protection standards and criticality controls are maintained.

Strategic Decision: Evaluation of the two alternatives, treating waste streams separately versus treating waste streams together, revealed clear advantages (cost, safety, and final disposition) to DOE- $\mathrm{D}$ in treating alpha and TRU mixed wastes with the same treatment process.

This recommendation is consistent with conclusions of a previous study performed by the DOE-ID Systems Analysis Division in 1993 (See Draft "INEL TRU and Alpha Low Level Waste Disposal Decision" Document). 


\subsection{Tactical Phase}

Once the decision was made to recommend treating alpha and TRU wastes together, the next level of decision making focused on tactical issues, i.e., how should the decision be implemented? This phase of the decision making process involved formulating feasible options and evaluating these options with respect to the objectives. Options evaluated were primarily derived from the private sector feasibility studies. Figure 4-5 illustrates an overview of the tactical phase.

\subsubsection{Formulate Options}

A. Private Sector Treatment

1) Sole Source

2) Off-site Location for Treatment Facility

3) M\&O Retrieval

4) Private Sector Turn-key (i.e. all work performed by private sector.

B. M\&O Treat-all to LDR.

\section{Goal: Dispose of INEL Mixed Waste in Safe and Permanent Manner}

Recommended Altemative: Treat Alpha and TRU Mixed Wastes to LDR

\section{Options}

1. Sole souree

2. Off-site Location

3. M\&OIWPF

4. M\&O Retrieval \& Private Sector Treatmert

5. Private Sector Turnkey
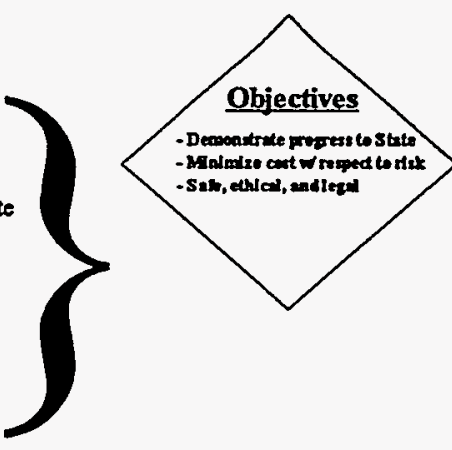
Recommended Options

Figure 4-5. Overview of Tactical Phase of Decision Making Process 
Two potential options, sole source treatment services and siting the private sector treatment facility off the INEL, were determined to be infeasible.

Sole Source - This option was rejected due to the requirements of the Competition in Contracting Act and implementing regulations. The team determined that procurement of waste treatment services does not meet the criteria for a sole source contract, i.e., national emergency, national security, unique capability. Furthermore, the consensus opinion was that competition would reduce the total cost of the project to DOE.

Off-site Location for Treatment Facility - This option was rejected due to an evaluation of the advantages and disadvantages of an off-site location. One of the feasibility studies suggested an off-site location for the treatment facility. The other two feasibility studies did not consider locating the facility outside of INEL boundaries.

The contractor which advocated an off-site location stated that "the conceptual design is totally adaptable to either a privately leased site within the INEL complex or an off-site location," and listed numerous advantages and disadvantages of siting the treatment facility at the INEL. Advantages cited include: close proximity to waste, existing site infrastructure, functional facilities (fire department and site security), activities related to D\&D, and absence of community and state fees. Disadvantages cited include: precedent in siting a private fixed price facility on Federal land, perceived delays with licensing and permitting, uncertainty of NEPA requirements, and the burden of DOE orders and oversight.

These concerns were discussed at length by the team members. It was the team's opinion that the disadvantages cited were more perceived than real. For example, there is precedent of siting a private facility on Federal land (U.S. Ecology Facility at Hanford). The team felt all issues could be adequately addressed by DOE, given sufficient time to identify and mitigate issues. DOE involvement in licensing and permitting of an off-site facility would be limited; however, DOE would still be somewhat involved; the team was unsure of the exact extent of DOE involvement. NEPA requirements are addressed in the site-wide EIS and DOE-ID would assume most of the burden of any supplemental NEPA requirements. Finally, the team determined that a "necessary and sufficient" set of requirements from DOE orders, i.e., ES\&H requirements, would be identified. In summary, private sector concerns regarding problems associated with siting a facility at the INEL were not well substantiated and insignificant relative to the advantages (cost and safety) of siting the treatment facility near the RWMC.

The SEG off-site feasibility study option was based on the premise that the scope of treatment services was restricted to alpha waste only. Although not verified, 
the DOE-ID Evaluation Team assumed that had the contractor been requested to treat all alpha and TRU waste types, the logistics of transporting large quantities of TRU waste in addition to alpha waste would have eliminated consideration of siting the facility outside the INEL.

Once the team made the strategic decision to recommend all mixed waste be treated to LDR, an off-site location was deemed infeasible for the following reasons:

1) Transport and Handling of TRU Wastes - approximately $60 \%$ of the waste is stored in boxes; these boxes would need to be repackaged prior to transport off-site because there is no approved TRU box transport system. This would require a characterization facility and a repackaging facility with an estimated life-cycle cost of $\$ 800$ million. Furthermore, transportation of treated TRU waste would have required TRUPACT containers. Construction of a private road from the RWMC to the private off-site treatment facility with restricted access was considered at an estimated cost of $\$ 10$ million (paid for by DOE).

2) Site infrastructure and emergency services could be utilized with an on-site location. Impact to existing site operations was perceived to be minimal.

3) - Discussions with NRC regarding licensing indicated that NRC's lack of licensing experience with this type of facility and NRC requirements for public involvement would delay the project and create additional avenues/opportunities for those opposed to thermal treatment which could result in further delays.

Eliminating the Sole Source and Off-site options resulted in formulation of three feasible options: (1) Private Sector Turn-key, (2) M\&O Retrieval and Private Sector Treatment, and (3) M\&O Treat-all to LDR. The next stage of the decision making process involved evaluating these options against the objectives.

\subsubsection{Evaluate Options with Respect to Objectives}

The following discussion highlights and qualifies comparison of alternatives relative to each objective. Table 4-2 summarizes treatment options with respect to the stated objectives. (Note: for the M\&O IWPF Option, the facility was assumed to be operational by 2010 with a 20 year operating life. All cost estimates are based on a 2010 starting date. Current DOE plans may delay the start-up until 2030 with treatment complete and all treated waste shipped to WIPP by 2050.) 


\section{Objective 1: Demonstrate Progress to State}

M\&O IWPF Treat-all to LDR - This option scored the lowest with respect to this objective. Waste treatment and disposal at WIPP is not completed until 2030.

M\&O Retrieval and Private Sector Treatment - This option scored high relative to this objective since treatment could begin in 1998-2001, and it is estimated that all waste would be shipped to WIPP by 2016, 14 years sooner than the M\&O option.

Private Sector Turn-key - This option scored highest relative to this objective since treatment could also begin in 1998-2001, and it is estimated that all waste would be shipped to WIPP by 2013. An accelerated retrieval schedule matched to the capacity of the treatment facility results in a two year savings from the M\&O Retrieval and Private Sector Treatment option and 17 years compared to the M\&O option.

Table 4-2. Evaluation of Feasible Options with Respect to the Objectives.

\begin{tabular}{|l|l|l|l|}
\hline $\begin{array}{l}\text { Treatment } \\
\text { Alternative }\end{array}$ & $\begin{array}{l}\text { Demonstrate } \\
\text { Progress to State }\end{array}$ & $\begin{array}{l}\text { Minimize Cost w/ } \\
\text { Respect to Risk* }\end{array}$ & $\begin{array}{l}\text { Safe, Legal, and } \\
\text { Ethical Conduct } \star *\end{array}$ \\
\hline $\begin{array}{l}\text { M\&O IWPF (retrieve } \\
\text { and treat-all waste } \\
\text { together to LDR) }\end{array}$ & TRU to WIPP by 2030 & $\$ 2.0$ billion & See footnote** \\
\hline $\begin{array}{l}\text { M\&O Retrieval \& } \\
\text { Private Sector } \\
\text { Treatment }\end{array}$ & TRU to WIPP by 2016 & $\$ 1.2$ billion & $\begin{array}{l}\text { Reduced DOE flexibility } \\
\text { w/private sector } \\
\text { involvement }\end{array}$ \\
\hline Private Sector Turn-key & $\begin{array}{l}\text { All waste to WIPP by } \\
2013\end{array}$ & $\$ 827$ million & $\begin{array}{l}\text { Reduced DOE flexibility } \\
\text { w/ private sector } \\
\text { involvement }\end{array}$ \\
\hline
\end{tabular}

* Total DOE/INEL costs

** The consensus opinion of the team was that there is no differences in safety, ultimate DOE liability, and real level of DOE control between options

\section{Objective 2: Minimize Cost with Respect to Risk}

M\&O IWPF Treat-all to LDR - This option, estimated at approximately \$2 billion, is significantly higher than the two competing options. It is more than twice the estimated cost of the Private Sector Turn-key option. The \$2B estimate , was provided by the LITCO cost estimating group. DOE-ID believes it is probably high. It is reasonable to assume that the M\&O IWPF alternative to treat 
all waste to the LDR standard should be slightly less than the \$1.6B estimate for the baseline case. All financial risks are borne by DOE; DOE provides funding for all capitalization, contract modifications, claims, etc. Budget vulnerabilities increase as a function of time, and this is the longest, most drawn out option. On the other hand, the relationship between DOE and the M\&O may be less adversarial due to DOE's M\&O performance incentives. Additional costs for extended WIPP operations are not included in the overall cost estimate.

M\&O Retrieval and Private Sector Treatment - It is estimated that this option would cost DOE substantially less than the M\&O option but approximately $\$ 400$ million more than the Private Sector Turn-key option. Financial risk is shared by DOE and the private sector, with the private sector providing capitalization for facilities associated with treatment. The private sector also provides insurance/surety. Associated WIPP costs may be reduced due to the earlier completion date. Budget uncertainties are somewhat reduced due to the project's lower cost and shorter duration. A major disadvantage of this option is the potential for DOE to incur significant delay and/or disruption claims from the private sector contractor due to change conditions if the $\mathrm{M} \& \mathrm{O}$ does not provide the private sector contractor retrieved waste in the contractually specified condition and at the specified rate. Also, DOE will be responsible for interim storage.

Private Sector Turn-key - This is the lowest cost option. It avoids the potential problems associated with an interface point between contractors thereby eliminating DOE's responsibility for interim storage. Retrieval can be performed just-in-time to minimize handling and storage. Similarly to the M\&O Retrieval and Private Sector Treatment option, financial risk is shared by DOE and the private sector, with the private sector providing capitalization for facilities associated with treatment. The private sector also provides insurance/surety. Associated WIPP costs may be reduced due to the earlier completion date. Budget uncertainties are further reduced due to even lower cost and shorter duration than the M\&O Retrieval and Private Sector Treatment option.

\section{Objective 3: Accomplish the Goal in a Safe, Ethical, and Legal Manner}

This objective was the most difficult to quantify. The team discussed safety, ethical, and legal issues at great length. Ethical DOE conduct involves accomplishing the mission at the lowest cost to the taxpayers, while maintaining safety standards and complying with applicable statutes. Thus, given the large disparity in cost and schedule between the private sector options and the M\&O option, the team was forced to address the following questions: 
1) What is DOE gaining from private sector involvement?

vs.

2) What is DOE giving up with private sector involvement?

The crux of these issues is illustrated in Figure 4-6, where risk is displayed in relative terms.

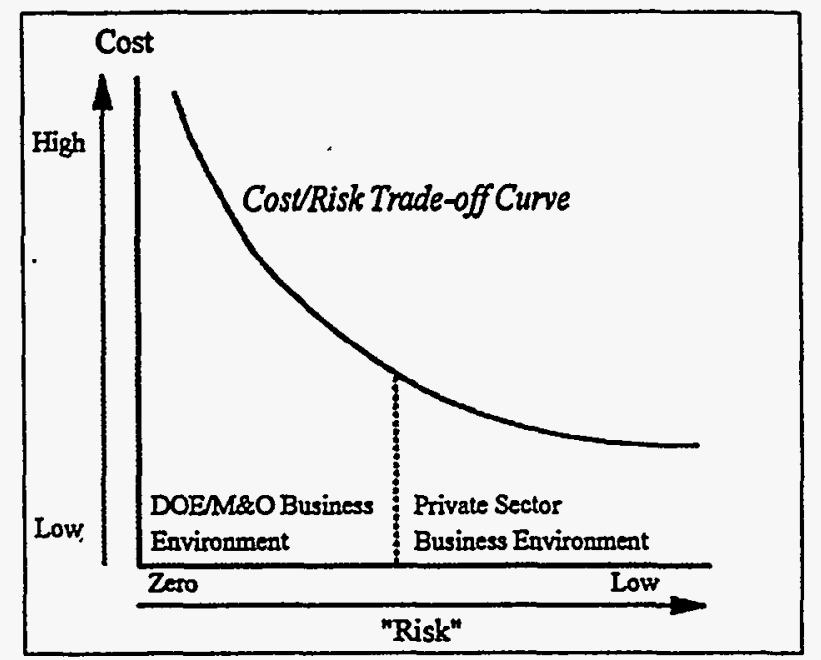

Figure 4-6. Conceptual Context of Private Sector Involvement: The Cost/Risk Trade-off Curve Differs for DOE versus the Private Sector.

What is DOE gaining? Assuming the private sector can perform the work at the estimated cost and in the estimated time frames, DOE gains tremendous cost savings. In addition, most waste is removed from Idaho up to 17 years sooner than with the $M \& O$ option.

What is DOE giving up? Traditionally DOE has strived to operate in a near riskfree environment, and as a result, DOE has an impressive record of safety. Conversely, a near risk-free culture comes at a high price, perhaps an unacceptably high price in the current budget environment. Privatization and the call for "DOE to function more like a business" essentially entails accepting slightly more risk in anticipation of large cost savings. It was the consensus opinion of the team that DOE would not compromise safety or environmental quality by utilizing private sector services for treatment of mixed waste. Furthermore, use of private sector treatment services does not increase nor limit the risk to DOE of catastrophic liability any more than with the M\&O-operated, DOE-owned IWPF. On the other hand, the team recognized the loss of DOE flexibility (not control) in utilizing the 
private sector under a fixed price contractual arrangement. In the event of budget perturbations or "change conditions", DOE has much less latitude and ability to redirect.a fixed-price contractor (without incurring substantial costs) versus the $M \& O$ under a cost-plus arrangement. In addition, project budget uncertainty may be reduced since it may be more difficult to remove funding from a fixed-price private sector contract than an $M \& O$. In summary, the consensus opinion of the team was that given the tremendous potential cost savings, DOE should be willing and able to surrender some flexibility within an acceptable level of environmental, health and safety risk.

Tactical Decision: After careful evaluation of the three options (M\&O IWPF Treatall, M\&O Retrieval and Private Sector Treatment, and Private Sector Turn-key), the team recommends that DOE pursue procurement of treatment, assay and characterization services for alpha and TRU mixed waste from the private sector. The contract may include a priced option for private sector retrieval and storage.

\subsection{Elements to be Considered in Follow-on Work and Proposed RFP}

\subsection{Technology Development Considerations}

Mixed waste treatment is a major thrust of the DOE Technology Development Program, so there are many ongoing activities which could potentially apply to the privatization of ALLMW and TRU treatment. In particular, several improvements to monitoring and control of thermal treatment off-gas systems are at various stages of development and demonstration. In addition, non-destructive examination and charactization are continuously being improved. For purposes of preparing an RFP, this ongoing research raises two considerations. First, a review should be made of the technical work scope just prior to issuance of the RFP to ensure that the latest technical knowledge is considered. Secondly, the RFP should have provisions for allowing the private sector easy access to DOE technology and technology services during the design, construction and operation of the treatment facility. The private sector should be able to witness demonstrations of promising technology and be able to host demonstrations or tests which might benefit the facility. DOE should be prepared to cost share in these demonstrations.

The regulatory environment for mixed waste is also dynamic. A careful review of recent development in transportation and RCRA testing methods should be conducted prior to issuance of the RFP. Leachability testing for the primary and secondary treatment products is an area of particular concern. The general trend has been to more aggressive tests to show non-leachability, which could eliminate grout based waste forms.

Restrictions on feeding volatile metals (lead, cadmium, mercury) to the primary treatment process could also severely impact privatization. Historically, the regulations have been quick to reflect improvements in the state of the art for effluent monitoring. The private sector should be encouraged to use the latest available technology in this area. 
Each of the studies identified some remote handled waste in the INEL inventory which could not be economically processed in the recommended system. These wastes included relatively high radiation materials with unusual configurations or material content (internal shielding, fuel pellets, and so on). These wastes will need special attention and may have to be dealt with in conjunction with the high level waste and/or spent fuel programs. The quantities involved are less than $1 \%$ of the total waste volume.

The trade-off for metal recycle should be more thoroughly evaluated while the RFP is being prepared. Metal recycled within DOE (or for free release) will likely have lower charges for separation, decontamination and survey than for full treatment, examination and certification for disposal. In addition costs for transportation and disposal at WIPP will be avoided altogether.

Other issues to be addressed prior to issuance of an RFP are should DOE determine: (1) a volume reduction level; (2) the final waste form; (3) if a $100 \%$ TRU waste product is desirable; and (4) a disposal plan for non-TRU wastes generated by treatment.

\subsection{Business Approach}

DOE-ID technical staff considered all three private sector (PS) solutions technologically feasible and collectively representative of sound thinking from both technical and business disciplines. The combinations of choices for treatment services from the PS becomes a business, as well as a technical decision.

\subsubsection{Financing and Office of Management and Budget (OMB) Scoring}

The DOE-ID evaluation of the PS feasibility studies resulted in a belief that industry is willing to accept the risk associated with fixed price contracting at a reasonable price.

Price is a function of the return required when a business considers alternatives among investments and their associated risk. The examination of the PS studies indicate that industry places risk at a real rate of return on investment of $15 \%$ of cost for this project. Internal rate of return and net present value analyses were used to validate all three PS studies. It is the opinion of the Business Subteam that the rate of return required by the private sector is reasonable.

Based on information provided from PS feasibility studies, the current recommendation is to divide the project into four phases. Phase $I$ of the project includes $\$ 3.5 \mathrm{M}$ for permitting (anticipated fixed price contract), and $\$ 3 \mathrm{M}$ for NEPA (DOE costs). These amounts would not require OMB scoring.

Phase II consists of construction and process demonstration to be financed by the private sector. Maximum total estimated costs for capital construction are \$70M. 
Assuming a contract award for Phase I in 1997, this amount would need to be OMB scored in FY 2000 as Budget Authority and would need to fit within Departmental targets. Budget outlay for the project during this phase is $\$ 14 \mathrm{M}$ per year for FY's 2000-2002, and \$28M in FY 2003 when Phase II ends. This covers the possibility of payment for termination for convenience during Phase III. If for. some reason the project does not reach the operational stage, the Department would still need to pay the private sector for their capital investment of $\$ 70 \mathrm{M}$. When the facility begins operation in 2003 , the $\$ 70 \mathrm{M}$ contingent liability would be reduced as the private sector capital investment is amortized on a per unit waste treated basis. The maximum annual estimated cost for treatment is $\$ 25 \mathrm{M}$ per year, which would include the amortized capital costs.

As discussed in Section 3.1.2, DOE-ID is evaluating the option of paying the private sector $\$ 70 \mathrm{M}$ at the end of Phase II in order to reduce the facilities capital cost of money, thereby decreasing the unit price. Current estimates indicate this would reduce annual operating costs significantly. In addition, there is an estimated $\$ 5 \mathrm{M}$ which will be required for infrastructure power upgrades at the RWMC prior to construction. The amounts reported above are in FY-94 dollars. See Figure 5-1 below for a visual description of the expected contract and funds flow. Note that the figure goes beyond the current budget planning horizon.

Phase III of this project represents the operating/treatment effort. If waste quantities are guaranteed to the private sector a contractual obligation of the Government would exist for the entire amount of the negotiated price for the guaranteed quantity. In this instance the entire amount of the contract (treatment included) would be OMB scored and funds set aside in advance for this amount to account for the liability. Therefore, the DOE-ID team recommends that no quantity of waste be guaranteed. This will allow flexibility in the event of termination for convenience without being required to pay for the entire amount, and eliminate the requirement to score operating costs. This approach will be reevaluated following preproposal comments.

Phase IV will be for D\&D of the treatment facility. Currently, the INEL has D\&D capability; however, a trade-off analysis of the advantages and disadvantages between private sector and the INEL has not been done. Regardless of the alternative chosen, DOE-ID will need to more specifically determine the criteria for D\&D. This phase could be priced as an option within an RFP for treatment services. Prior to issuance of an RFP, D.OE-ID needs to determine the level of decontamination required (e.g., greenfields vs. non-greenfields). 


\subsubsection{Contracting Approach}

Given the diversity in the nature of work in the different phases of the contract, the following contract structure is recommended at this time. The recommended contracting structure will be re-evaluated before release of the RFP. The reevaluation will take into account comments from a preproposal meeting with "potential contractors and DOE-ID's most current evaluation of the department's best interests. Each of the phases identified in Figure 5-1 below will be an . independently negotiated portion of the contract document specifying decision criteria, deliverables and other final product requirements as prerequisites to the award of the next phase. The funds for the "termination penalty" would need to be available at time of contract award.

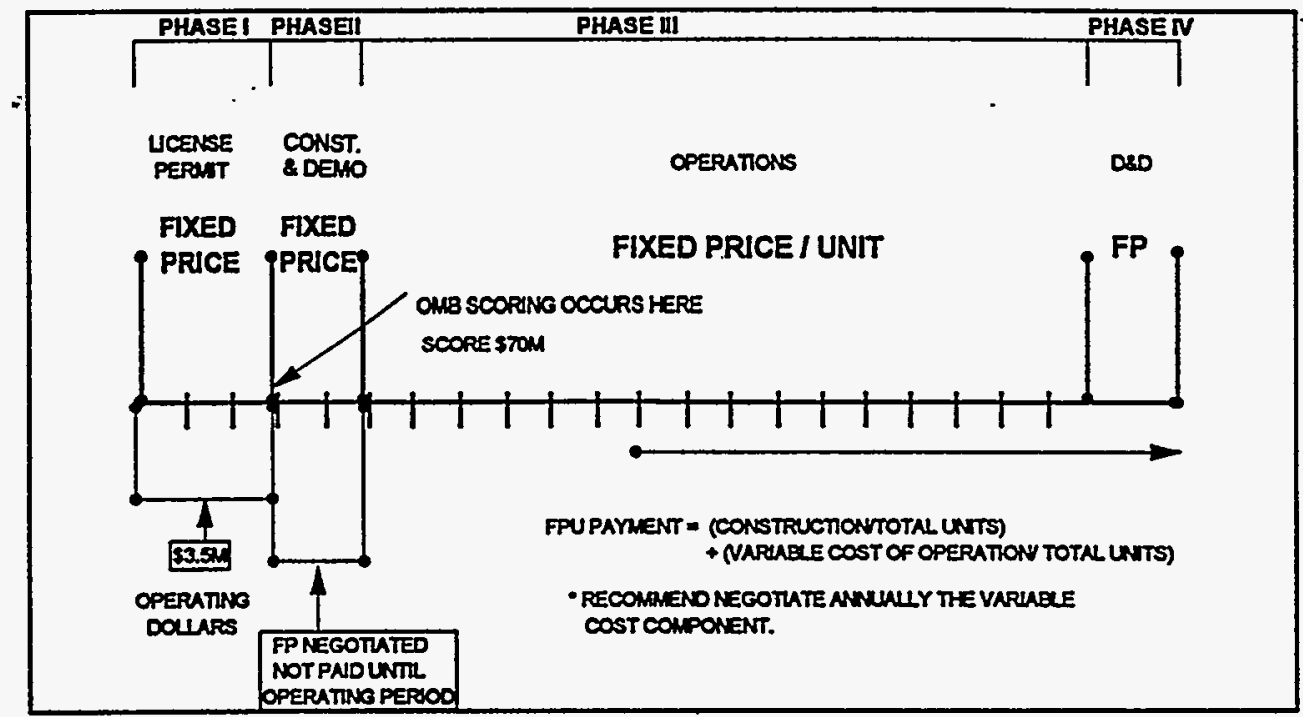

Figure 5-1. Expected Contract and Funds Flow.

- The private sector appears willing to assume the risk associated with a fixed price contract for construction and operations. Further it was determined that the SOW associated with treatment through disposal can be developed with sufficient certainty and flexibility to allow the negotiation of a fixed price per unit contract which shifts the risk of performance to the private sector. (Reference Figure 5-1 above) 


\section{Phase I}

\section{Licensing/Permitting/Design/Development - Firm Fixed Price}

- Incentives have been mentioned for this activity with reward for early completion and cost savings.

\section{Phase II}

\section{Construction - Firm Fixed Price}

- Firm fixed price with no progress payments. The contractor will recover expenses for construction of the facility through amortization over the treatment period. This amount must be OMB scored. Activities associated with the Operational Readiness Review and Trial Burn could use operating dollars.

- Options for payment of construction costs at completion of construction are under consideration.

\section{Phase III}

\section{Operations - Fixed Price per Unit}

- Based on technical considerations, the RFP could offer INEL assets as Government Furnished Equipment to the private sector. The private sector could then consider inclusion of the offered Government Furnished Equipment in their responses and cost estimates. Facilities considered as possible Government Furnished Equipment include: the TSA-RE, SWEPP, WCF, the Type II storage buildings. Some of these facilities are under construction and some are in the planning stage.

\section{Phase IV}

\section{Decontamination and Decommissioning (D\&D) - Firm Fixed Price}

The RFP must be specific as to the extent of D\&D requirements. The basis for this effort could be the INEL historical D\&D costs for similar facilities with similar contamination. The RFP should require the contractor to defend the adequacy of the allowance for future D\&D costs. 


\subsubsection{Other Contracting Considerations}

\subsubsection{Sole Source vs. Competition}

It has been suggested that the ALLMW treatment contract be awarded on a sole source basis. DOE-ID does not believe this is legal or advisable for several reasons. First, the Competition in Contracting Act (CICA) and the requirements of the Federal Acquisition Regulations (FAR) implementing CICA allow for sole source awards only in certain prescribed circumstances; however, none of these circumstances, found in 41 U.S.C. 253(c) and FAR Subpart 6.3, applies to the ALLMW Project. Therefore, full and open competition should be pursued. Second, the Secretary of Energy's Contract Reform Initiative reveals a strong preference for competition for contract awards made by DOE and its contractors. Third, the results of the feasibility studies suggest that competition would be in DOE's best interest. Consequently, the ALLMW Project contract will be awarded on the basis of full and open competition.

\subsubsection{Terms and Conditions}

Standard contract terms and conditions which reflect Contract Reform objectives will be provided in the RFP. The feasibility study contractors have suggested several deviations to standard FAR clauses (advance payment under fixed price, limitation of assessment of costs under termination for default, increases in amount of costs recoverable under termination for convenience). It is advisable to inform prospective offerers that any requested changes to standard FAR clauses must be called out in proposals and DOE will take them into consideration during the selection process. It is not advisable to make the requested changes to standard FAR clauses in the solicitation prior to respondents requesting them.

The nature and severity of any deviations to these standard clauses can only be assessed in the review of proposals and in negotiations. Given the nature of the project and the strong trend towards fixed price incentive contracting, it is probable that unique terms and deviations will be required in the areas of contract financing and payments, in equitable sharing of risks (which could result in lengthy clauses concerning termination rights) and in indemnification of parties. It should be noted that any deviations must be approved by DOE Headquarters which may add additional time to the award schedule. 


\subsubsection{Liability and Contract Clauses}

It is assumed that the bulk of the work under the ALLMW project will be done on a firm fixed price basis, thereby transferring the maximum risk to the contractor. Therefore, DOE should consider including the following clauses in the contract:

1) The Property clause found in FAR $\S 52.245-2$, which imposes the risk of loss of Government furnished property on the contractor;

2) The Insurance clause, found either in FAR $\S 52.228-5$ or in the Pit 9 subcontract, making clear the cost of insurance (including insurance to protect against the risk of loss to Government furnished equipment) is at the contractor's own expense.

3) The contract should include a rather broad indemnity clause that requires the contractor to hold DOE harmless from all claims (including civil penalties) arising from the contractor's performance of its contract. This is particularly important in light of the Idaho Division of Environmental Quality's practice of issuing notices of violation under RCRA and the Clean Air Act against DOE even though the violations in question were the contractor's responsibility. A variation of the indemnity clauses found in the Pit 9 subcontract should be adequate to accomplish this objective.

4) The contract should also include a clause similar to the Pre-existing Conditions clause that is being developed as part of the so-called sample contract provisions for DOE's for-profit contracts. This clause relieves the contractor of any claim or remediation obligation arising from conditions pre-dating the effective date of the contract; however, to the extent the contractor's actions or inactions cause or add to such claim or obligation, the contractor is responsible.

5) Also being developed as part of the sample contract provisions is an environmental, safety, and health clause that will allow DOE, among other things, to properly enforce its occupational safety obligations under the Occupational Safety and Health Act.

6) The contract will likely include a provision for payment of a termination penalty, equivalent to the contractor's reasonable unamortized design and construction costs, in the event DOE terminates the contract prematurely. If DOE pays the termination 
penalty, the contract should provide the option for DOE to take title to the property (including designs) covered by the penalty.

7) DOE should include the appropriate intellectual property clauses.

8) The foregoing clauses are the more notable clauses to be included. Other clauses that are required by statute should be included.

\subsubsection{Price Anderson Considerations}

Performance by a contractor of work under the ALLMW project will involve the risk of public liability, as that term is defined in the Atomic Energy Act; consequently, DOE will need to include the Nuclear Hazards Indemnity Agreement, DEAR $\S 952.250-70$. Inclusion of this clause, together with its mandatory flow-down in subcontracts involving the risk of public liability, will subject the contractor and covered subcontractors to the requirements of DOE's nuclear safety regulations that have been issued or will soon be issued (10 CFR Parts 820, 830, 834, and 835).

\subsubsection{Leasing}

The contract should include a lease clause under which the contractor is given the right to use DOE's property at the INEL in carrying out the contract. Inclusion of this clause will provide the parameters under which the contractor has the right to use DOE's property; and any proposed use that exceeds these parameters (such as using the facility for non-DOE work) will require DOE-ID's prior approval. For this type of a project, DOE should have no trouble entering into a long term lease (if needed) under $\S 161 \mathrm{~g}$. of the Atomic Energy Act.

\subsubsection{Interest vs. Cost of Money}

Some study participants included interest expense in their studies. Interest is unallowable per FAR 31.205-20. However, the Government can provide for Cost of Money (COM) applicable to the investment in tangible capital assets under construction and facilities capital employed during treatment. The contractor must request COM in their proposal submission, as COM cannot be considered after negotiations. The COM associated with assets under construction is included in the capitalized value of the asset and amortized over the useful life of the capital assets or the treatment period. The COM associated with facilities capital will be accumulated during construction and payable on a fixed price per unit basis during treatment. Facilities capital COM does not apply to facilities on which compensation 
is based on "use rates" or allowances. Facilities capital COM applies to only facilities that are depreciated. The COM calculation uses the applicable interest rates determined by the Secretary of the Treasury under Public Law 92-41, 85 Statute 97. Payment of construction costs at the end of Phase II would eliminate the need for payment of COM over the period of operations.

\subsubsection{Procurement Schedule}

It is anticipated that a competitive procurement will take approximately 20 months. Refer to the schedule in Appendix B for an abbreviated milestone schedule.

\subsubsection{Organizational Conflicts of Interest}

As indicated above, the proposed ALLMW contract will be a prime contract with DOE, thereby eliminating organizational conflicts of interest (OCI's) which might otherwise be present if the work were performed through a subcontract with Lockheed Idaho Technologies Company (LITCO), DOE-ID's current M\&O contractor. Even so, OCI's could arise from a number of sources, including DOE's use of certain LITCO employees as technical advisors in developing data and other support roles related to the development of treatment technologies or the proposed procurement. Consequently, DOE is taking the following steps to avoid or mitigate any OCI's or personal conflicts of interest:

- DOE-ID is developing an OCI mitigation plan, critical features of which are: (a) only DOE personnel will make decisions with regard to procurement strategies; (b) LITCO employees will provide only technical support; and (c) all LITCO employees who support DOE will sign confidentiality agreements.

- DOE-ID will strictly enforce: (a) the OCI provisions of DEAR Subpart 909.5; (b) the personal conflict of interest provisions of FAR Part 3 and DEAR Part 903; and (c) the LITCO OCI Compliance Plan, which is part of the LITCO prime contract.

\subsection{Labor Considerations}

Carrying out the ALLMW project will be "new work" such that DOE's contracting of this activity (1) should have a minimal impact on LITCO's current workforce, and (2) should not result in a successor employer situation. Since DOE is not a party to any collective 
bargaining agreement with any employees potentially affected by the project, there are no bargaining issues.

The most significant labor considerations are including a provision in the RFP and resulting contract that (1) requires the contractor to become a signatory to the INEL's Site Stabilization Agreement, and (2) requires the contractor to comply with the requirements of $\S 3161$ of the National Defense Authorization Act for Fiscal Year 1993. Regarding the latter item, DOE could include an incentive in the RFP to give some preference to those offerors willing to hire those employees eligible for the 3161 hiring preference.

\subsection{Infrastructure Needs}

If located at the INEL, new projects are required to provide the necessary infrastructure requirements to support proposed facility operations unless specifically identified. Infrastructure considerations would include: electrical power, sanitation, water, refuse services, roads, telephone and communication lines, and general storage accommodations.

Examples of specific infrastructure considerations include the following:

1) The State of Idaho currently will not allow additional septic systems at the INEL. The contractor would likely be required to determine the availability of existing treatment facilities to support proposed operations, expand existing facilities, or provide new facilities.

2) Electrical power at the INEL currently has limited additional resources. For example, it is estimated that a $\$ 5 \mathrm{M}$ project upgrade for power lines will be needed for this project should it be located near the RWMC. Such an upgrade would require a new substation at the RWMC or that the substation at the Power Burst Facility be upgraded. This system would need to be compatible with the RWMC system.

3) All new facilities would be required to provide water storage and distribution systems capable of supporting their specific operations, potable water and fire fighting needs. While there is a well approximately one mile for RWMC, it is currently being used by an existing project. Availability of the well would have to be determined and could not affect operations at the existing facility.

4) While existing landfill operations are provided for INEL facilities, cost free use cannot be assumed. The contractor will be required to obtain services and/or landfill accommodations. 
5) All necessary roads required independent of existing INEL roadways will likely be the responsibility of the contractor, as would road repair and snow removal.

\subsection{Concluding Remarks}

\section{Total Cost}

Schedule 1 below includes the turn-key impact of the relationship between the treatment process and the other processes to final disposal. In all the processes discussed, it is clear that increases in schedule results in added cost with no added value. The private sector turn-key cost savings are the result of the private sector controlling their own schedule.

SCHEDULE 1

\section{INEL ALLMW AND TRU WASTE TOTAL DISPOSAL COST COMPARISON BY STAGE OF OPERATIONS}

\begin{tabular}{|c|c|c|c|c|}
\hline & $\begin{array}{l}(\$ 000) \\
\text { IWPF }\end{array}$ & $\begin{array}{c}(\$ 000) \\
\text { PRIVATE SECTOR }\end{array}$ & $\begin{array}{c}(\$ 000) \\
\text { SAVINGS } \\
\end{array}$ & $\begin{array}{c}\text { DELTA } \\
\%\end{array}$ \\
\hline TREATMENT & $\$ 619,771$ & $\$ 383,310$ & $\$ 236,461$ & $38 \%$ \\
\hline RETRIEVAL & $\$ 70,413$ & $\$ 18,201$ & $\$ 52,212$ & $74 \%$ \\
\hline STORAGE & $\$ 320,529$ & $\$ 201,307$ & $\$ 119,222$ & $37 \%$ \\
\hline EXAMINATION & $\$ 512,220$ & $\$ 147,134$ & $\$ 365,086$ & $71 \%$ \\
\hline TRANSPORTATION & $\$ 124,390$ & $\$ 77,085$ & $\$ 47,305$ & $38 \%$ \\
\hline TOTAL COST & $\$ 1,647,323$ & $\$ 827,037$ & $\$ 820,286$ & $50 \%$ \\
\hline $\mathrm{m}^{3}$ PROCESSED & 64,730 & 64,730 & 64,730 & N/A \\
\hline COST $/ \mathrm{m}^{3}$ PROCESSED & $\$ 25,449.14$ & $\$ 12,776.72$ & $\$ 12,672.42$ & $50 \%$ \\
\hline YEAR COMPLETE & 2021 & 2013 & 8 & $33 \%$ \\
\hline
\end{tabular}

Treatment - Private sector treatment in the turn-key scenario saves DOE $\$ 236 \mathrm{M}$ or $38 \%$ over the current M\&O solution. These savings to a major degree are the result of private sector efficiencies and schedule improvements. In the M\&O treatment scenario, alpha waste is treated to LDR but the TRU waste is repackaged to meet WIPP WAC. In the private sector scenario, the contractor 
assumes a single system responsibility in which they-retrieve, assay, characterize and treat alpha and TRU waste to LDR only. There is no segregation of alpha and TRU waste by the private sector. The single system concept is also desirable because it eliminates the expensive change order process present when multiple entities are required to interface and share responsibility for retrieval, assay, and characterization. This is acute when a supplier of waste (INEL) has unplanned schedule delays which impact the processing schedule of the private sector.

The result is a $38 \%$ cost savings and an eight year schedule variance of early delivery to WIPP by the private sector turn-key operation.

Retrieval - The $74 \%$ cost savings directly reflects the efficiencies associated with improved design and process over the $M \& 0$ solution.

Storage - The 37\% cost savings by the private sector are directly due to treatment start dates. The M\&O scenario has a treatment start date of 2010 where the private sector could begin treatment in 1998 . The delayed start date by the M\&O will require doubling the number of Type II storage facilities and lengthen schedules. The additional schedule also increases costs for storage programs, hotel, utilities, and maintenance.

Examination - The $71 \%$ cost savings by the private sector are due to the differences in the method of examination which impact the schedule. The M\&O assay and characterization include segregation of alpha and TRU in the SWEPP facility. The private sector assay is included in treatment and does not require segregation of alpha and TRU which translates to savings. The INEL baseline solution requires operation of a WCF to certify compliance with the WIPP WAC. The private sector solution does not require a WCF because the primary waste form produced from the process is more easily characterized, which significantly reduces costs.

Transportation - The $38 \%$ cost savings by the private sector is due directly to the net volume reduction of a minimum of $68 \%$ which translates to $\$ 47 \mathrm{M}$ saved.

Infrastructure - The DOE infrastructure requirements require $\$ 5 \mathrm{M}$ in power upgrades for the private sector alternative. These improvements are included in the both treatment estimates. 


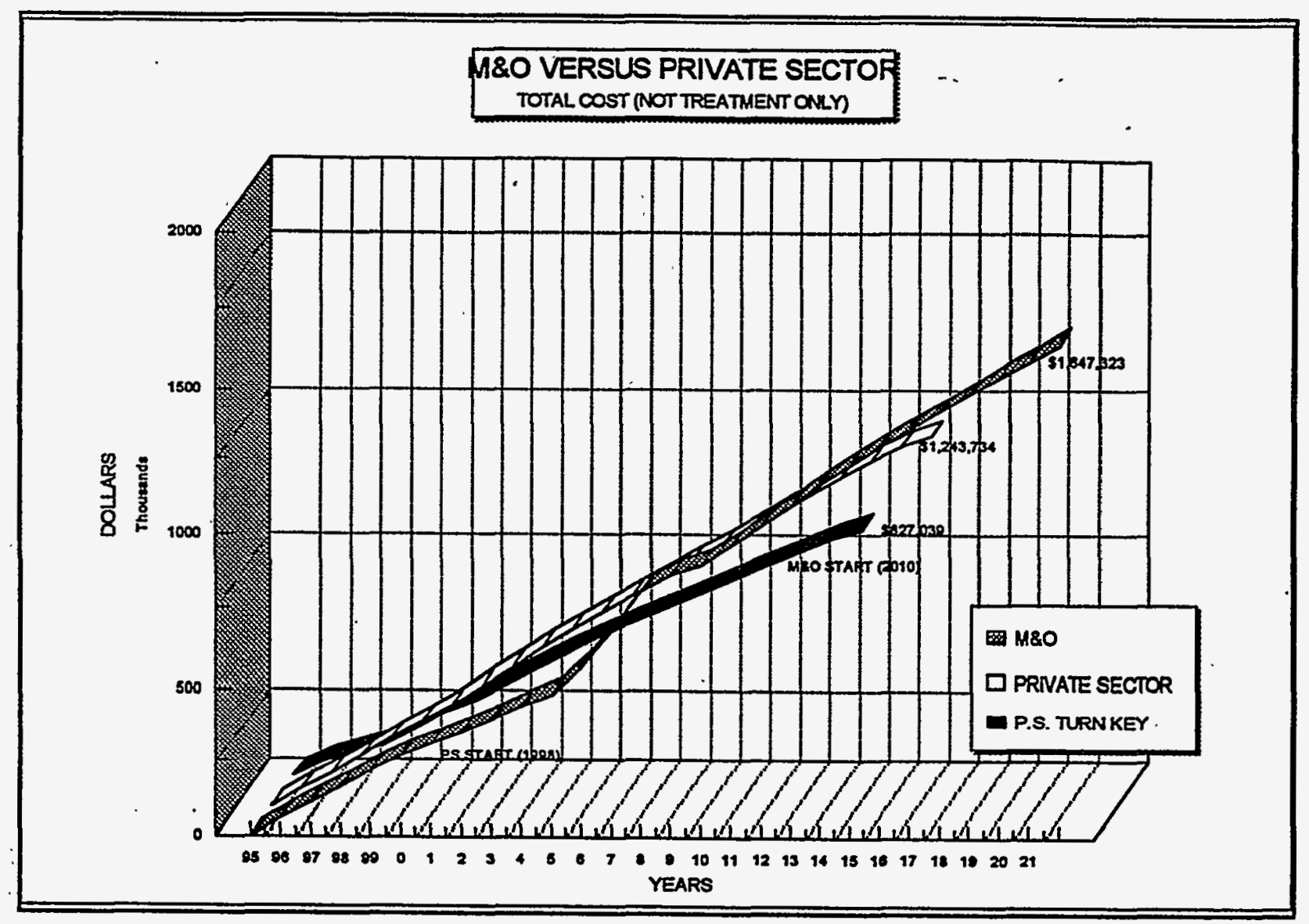

\section{Conclusion}

Schedule 2 is a graphic presentation that demonstrates how schedule affects cost. Given that the technical evaluation concluded that all three private sector solutions are feasible, the business decision of the DOE-ID team supports the private sector turn-key solution on a purely cost savings basis.

\subsection{Impacts on Existing Programs and Projects}

\subsection{WIPP}

\subsubsection{National Potential Implications to the TRU Waste Program}

The INEL cost evaluation demonstrates a large economic driver to treat the INEL's stored ALLMW and TRU waste to LDR standards using private sector treatment services. Given the potential savings at the INEL, it seemed logical to 
see if these savings could be extended to the rest of the DOE complex. The cost evaluations in this section of the report are preliminary. They are presented to demonstrate the potential impact to the DOE complex. The actual impact requires more examination with the cooperation of the National TRU Program and the other DOE sites responsible for ALLMW and TRU waste.

Two DOE complex-wide scenarios were evaluated. The "National" scenario assumes one private treatment facility for ALLMW and TRU waste located at the INEL. The "Regional" scenario assumes two private treatment facilities. One is located at the INEL and the other at the Oak Ridge National Laboratory (ORNL). If transportable, ALLMW and TRU waste requiring treatment before disposal is processed at one of these facilities. In the regional scenario waste from Hanford, Rocky Flats, Los Alamos, and the Nevada Test Site is treated at the INEL (7,016 $\mathrm{m}^{3}$ ), in addition to the INEL's $65,000 \mathrm{~m}^{3}$. Waste from the rest of the DOE complex is treated at ORNL $\left(4,330 \mathrm{~m}^{3}\right)$.

The contact handled stored TRU waste volumes reported in Revision 10 to the Integrated Data Base (December 1994) were used for this analysis. The quantity of this waste that will require treatment and the ability to transport this waste in TRUPACT IIs is uncertain. Revision 2 to the TRU Baseline Inventory Report is expected to address these uncertainties later this year. In the absence of better information, INEL estimates were projected across the complex. It was assumed that 50 percent of the non-INEL TRU inventory could be transported and that half of the transportable quantity would require treatment. The other half of the transportable quantity would be directly shipped to WIPP. It is recognized that this is not a complete solution. The non-transportable quantity of non-INEL (nonINEL and non-ORNL in the regional scenario) TRU waste would remain in place awaiting either on-site treatment or an enhanced TRU transport system. Based on the IDB report, approximately $18 \%$ of the TRU inventory would be nontransportable.

The cost evaluation includes the cost to load TRUPACT IIs and to operate the transporter. These costs are based on INEL experience shipping TRU waste in TRUPACT IIs between the Radioactive Waste Management Complex (RWMC) and ANL-W. Non-INEL costs to characterize the waste for transport are not included. Characterization for transport could be very expensive. In the INEL scenario, examination costs range from $50 \%$ to $82 \%$ of treatment costs. Nonetheless, with current projected estimates of $\$ 4.9 \mathrm{~B}$ from Federal Facility Compliance Act Site Treatment Plans for TRU wastes, there would appear to be an opportunity for significant cost savings. The cost to construct and operate a second private sector facility at ORNL is based on scaling the private sector estimates provided in the INEL feasibility studies. The private sector facility was scaled to be half of the capacity of the INEL facility. 
Using the INEL private sector treatment only costs (left half of Table 6-1), the total cost to the DOE complex was calculated by the computer simulation model for the National and Regional Scenarios. The National Scenario shows a marginal increase of less than $\$ 200 \mathrm{M}$ to treat the transportable volume of the TRU waste in the complex at the INEL (compared to the INEL cost alone). The Regional Scenario shows a slightly higher cost to the DOE complex compared to the National scenario. This is to be expected on the basis of economies of scale for a larger facility. Using the INEL private sector turn-key costs (right half of Table 6-1), the total cost to the DOE complex was calculated. 
Table 6-1. Alternative Plans for TRU and Alpha Contaminated Waste.

(M\&O Involvement)

\begin{tabular}{|c|c|c|c|c|c|c|}
\hline $\begin{array}{l}\text { Dollars in Constant } \\
\text { FY-94 (SM) }\end{array}$ & $\begin{array}{l}\text { (SM) } \\
\text { INEL } \\
\text { ONLY }\end{array}$ & $\begin{array}{c}(\text { SM) } \\
\text { NATIONAL } \\
\text { TREATMENT } \\
\text { CENTER } \\
\text { AT INEL }\end{array}$ & $\begin{array}{c}\text { (SM) } \\
\text { TWO } \\
\text { REGIONAL } \\
\text { TREATMENT } \\
\text { CENTERS } \\
\text { INELAND } \\
\text { ORNL }\end{array}$ & $\begin{array}{l}\text { (SM) } \\
\text { INEL } \\
\underline{\text { ONLY }}\end{array}$ & $\begin{array}{c}\text { (SM) } \\
\text { NATIONAX } \\
\text { TREATMENT } \\
\text { CENTER } \\
\text { AT INEL }\end{array}$ & $\begin{array}{c}\text { (SM) } \\
\text { TWO } \\
\text { REGIONAL } \\
\text { TREATMENT } \\
\text { CENTERS } \\
\text { INELAND } \\
\text { ORNL }\end{array}$ \\
\hline TOTAL INEL COST & $\$ 1,243$ & $\$ 1,360$ & $\$ 1,331$ & $\$ 827$ & $\$ 926$ & $\$ 897$ \\
\hline DIRECT SHIP TO WIPP & & $\mathbf{\$ 2 8}$ & $\$ 28$ & & $\$ 28$ & $\$ 28$ \\
\hline TRANSPORT TO INEL & & $\$ 40$ & $\$ 27$ & & $\$ 40$ & $\$ 27$ \\
\hline TREATMENT AT ORNL & & & $\$ 163$ & & & $\$ 163$ \\
\hline TRANSPORT TO ORNL & & & $\$ 9$ & & & $\$ 9$ \\
\hline DOE COMPLEX TOTAL & & $\mathbf{S 1 , 4 2 8}$ & $\mathbf{S 1 , 5 5 8}$ & & $\$ 994$ & $\mathbf{S 1 , 1 2 4}$ \\
\hline$\rightarrow$ & & & & & & \\
\hline $\begin{array}{l}\text { DISPOSAL COMPLETION } \\
\text { DATE }\end{array}$ & 2016 & 2019 & 2018 & 2013 & 2016 & 2018 \\
\hline $\begin{array}{l}\text { VOLUME DISPOSED AT } \\
\text { WIPP (M3) }\end{array}$ & & & & & & \\
\hline $\begin{array}{l}\text { VOLUME DISPOSED } \\
\text { TREATED TO WAC }\end{array}$ & & 9,825 & 9,325 & & 9,825 & 9,325 \\
\hline $\begin{array}{l}\text { VOLUME DISPOSED } \\
\text { TREATED TO LDR }\end{array}$ & 20,840 & 24,010 & 24,100 & 20,840 & 24,010 & 24,100 \\
\hline TOTAL VOLUME & 20,840 & 33,835 & 33,425 & 20,840 & 33,835 & 33,425 \\
\hline
\end{tabular}

(Private Sector - No M\&O) 
DOE complex. Further evaluation by the National TRU Program and the other DOE sites responsible for the ALLMW and TRU waste is warranted.

\subsubsection{Impact of INEL Decision to Treat TRU on the WIPP "No Migration Petition"}

WIPP must obtain approval from the State of New Mexico on their RCRA Part B Permit under Part 264 on landfills. However, WIPP is petitioning EPA through Part 268 to obtain an exemption from the section containing LDR requirements. Approval of the petition does not affect the need for a RCRA Part B Permit. EPA had approved a "No Migration Petition" determination for WIPP for the demonstration phase only, not the actual disposal phase.

An INEL decision to thermally treat TRU waste may impact the contents of the "No Migration Petition" since the INEL has the largest quantity of stored waste planned for WIPP disposal. The recommendation of this study to treat TRU waste is based on cost effectiveness for the INEL site, and the particular circumstances which exist with co-location of alpha and TRU waste, as well as the large volume of TRU waste in boxes which cannot be shipped without treatment or repackaging. For the waste existing in the remainder of the complex, DOE-ID believes, a "No Migration Determination" is needed.

As described in Section 6.1.1 above, for the remainder of the complex . approximately 25 percent of the total TRU waste could be shipped directly to WIPP. The INEL would thermally treat only that waste which does not meet the WIPP WAC requirements.

DOE-ID views that this approach could improve EPA's acceptance/approval of the "No Migration Petition." Gas generation is of significant concern to EPA, WIPP, and the State of New Mexico. If waste is thermally treated, gas generation will be greatly reduced (corrosion of the drums and any metal inclusions will still generate gas). Additionally, a known waste form (durability and density) is viewed positively.

Of concern is the WIPP performance assessment. If the INEL opts for a glass waste form, the issue of maximum radionuclide concentrations allowable will require evaluation. Preliminary scoping calculations indicate expected concentrations will not be a problem. In any case, the maximum concentrations can be controlled during treatment processing to ensure allowable levels would not be exceeded. No free metals (other than the containers) would be present, which would resolve potential gas generation.

Prior to issuance of an RFP, communications with DOE Albuquerque, the 
Carlsbad Area Office, and Sandia National Laboratories (SNL) must occur. SNL plans on issuing the performance assessment for WIPP in December 1996.

The INEL will need to work closely with SNL regarding changed requirements to determine impacts to a waste treatment services contract.

\subsection{Impact to Other Sites}

Potential savings to the complex could be realized if other sites participate in this procurement action. Other Western region sites such as Hanford, Rocky Flats, Nevada Test Site, Los Alamos, and Lawrence Livermore have waste which could be treated at this facility. Dialogue with some of these sites has begun; all should be contacted within the next 60 days.

\subsection{DOE Project Schedule}

The feasibility studies assumed an RFP award in 1995. DOE planning and budget cycles will likely preclude a contract award earlier than FY-1997. Using the WIPP closure dates of 2018, a high level schedule follows. Because this report used constant FY-94 dollars, the delayed start-up date should not affect the reported cost comparisons. The previously reported completion dates obviously slip back in time to reflect the actual contract award date.

Key Project Dates:

\begin{tabular}{|c|c|c|}
\hline 年 & Start & Finish \\
\hline Develop RFP and Award & $12 / 1 / 95$ & $8 / 1 / 97$ \\
\hline NEPA & $4 / 1 / 96$ & $4 / 1 / 98$ \\
\hline \multicolumn{3}{|l|}{ Phase I } \\
\hline Private Sector Design and Development & $8 / 2 / 97$ & $2 / 2 / 00$ \\
\hline Phase I Permitting & $8 / 2 / 97$ & $3 / 2 / 01$ \\
\hline \multicolumn{3}{|l|}{ Phase II } \\
\hline Private Sector Construction & $2 / 2 / 00$ & $2 / 2 / 02$ \\
\hline RCRA Part B Trial Burn & $2 / 2 / 02$ & $8 / 2 / 02$ \\
\hline \multicolumn{3}{|l|}{ Phase III } \\
\hline Treatment of INEL waste & $2 / 2 / 03$ & 2014 \\
\hline Treatment of off-site waste & $2 / 2 / 05$ & 2016 \\
\hline Treated waste to WIPP & 2003 & 2016 \\
\hline WIPP opening & 1998 & 2018 \\
\hline $\begin{array}{l}\text { Waste from INEL currently } \\
\text { meeting WIPP WAC }\end{array}$ & 1998 & 2016 \\
\hline Treated waste to WIPP & 2003 & 2016 \\
\hline
\end{tabular}

OMB scoring must occur in FY-2000 for Phase II of the contract. 


\subsection{Next Steps/External Communications Plan and Approval Plan}

As discussed in Section 1.0 of this report, there are no identified funds for a project of this size. An implementing project plan, project schedule, and budget requests will be developed by June 30, 1995. Immediate communication and coordination with LITCO, the DOE-ID M\&O contractor must occur, since some of their current work scope (retrieval, assay, characterization) will be effected by a DOE decision to implement the recommendations of this report.

An External Communications and Approval Plan is contained in Appendix D. 
FEASIBILITY STUDY REVIEW TEAM

Appendix A

\begin{tabular}{|c|c|}
\hline Overall Review & $\begin{array}{l}\text { Jamie Johnson and Jane Talarico, EM-351 } \\
\text { Frank Schwartz } \\
\text { Karl Hugo } \\
\text { Bill Leake } \\
\text { Jan Chavez }\end{array}$ \\
\hline Public Acceptance & Bob Brown \\
\hline $\begin{array}{l}\text { Technologies, Materials Handling, Waste } \\
\text { Acceptance Criteria }\end{array}$ & $\begin{array}{l}\text { Tom Williams } \\
\text { Bill Owca } \\
\text { John Kolts } \\
\text { Glenn Nelson } \\
\text { Gary Anderson }\end{array}$ \\
\hline TRU Program & $\begin{array}{l}\text { Jerry Wells } \\
\text { Tom Clements }\end{array}$ \\
\hline $\begin{array}{l}\text { Retrieval/Storage, and Waste Characterization } \\
\text { Interface }\end{array}$ & $\begin{array}{l}\text { Bill Lattin } \\
\text { Art Mantlik }\end{array}$ \\
\hline $\begin{array}{l}\text { RWMC Interface } \\
\text { Infrastructure }\end{array}$ & $\begin{array}{l}\text { Jeff Perry } \\
\text { D. Herrin }\end{array}$ \\
\hline Safety and Radiological Controls & $\begin{array}{l}\text { Richard Dickson } \\
\text { Patrick Smith }\end{array}$ \\
\hline Transportation & Mark Howard \\
\hline Regulatory & $\begin{array}{l}\text { Jack Depperschmidt } \\
\text { Dave Wessman } \\
\text { Roger Twitchell } \\
\text { John Medema } \\
\text { Bob Starck } \\
\end{array}$ \\
\hline Business Aspects & $\begin{array}{l}\text { Jerald Barbre } \\
\text { Faye Alexander } \\
\text { Joe Lee } \\
\text { Wade Hillebrant } \\
\text { Jim Schafer } \\
\text { Kelly Lemons }\end{array}$ \\
\hline Systems Approach & $\begin{array}{l}\text { Gary Schneider } \\
\text { Larry Redd }\end{array}$ \\
\hline Legal & $\begin{array}{l}\text { Mark Olsen } \\
\text { Scott Van Lente }\end{array}$ \\
\hline
\end{tabular}


1 Funding Reserved / PR Received

2 Acquisition Plan Prepared

6

7

\section{8}

13 Preproposal Conference

14 Closing Date/Receive Proposals

15 SEB begins Evaluations

16 SEB Completes Initial Evaluations

17 Competitive Range Report Complete

18 Competitive Range Presentation to SSO

19 Ques / Deficiencies to Comp. Range

20 Pre-Negotiation Plans Complete

21 Responses Due

22 Written or Oral Discussions incl. Negot. of Ts \& Cs and cost complete

23 Request BAFOs

8 Incorporate IR Comments

Final RFP - HQ Bus. Clear. Review

32 Notification to Successful Offerors

33 Notification to Unsuccessful Offerors

34 Government Signature (date of award)

35 Debrief Unsuccessful Offerors

36 Complete Post Award Orientation

$\begin{array}{cc}0 & 0 \\ 14 & 14\end{array}$

$5 \quad 19$

90

0

10

7

30

21

30

14

$0 \quad 613$


Table C-1. Total Alpha and TRU Quantities in Complex and Projected Facility Costs

\begin{tabular}{|c|c|c|c|c|c|c|c|}
\hline Site Name & $\begin{array}{c}\text { '94 IDB CH } \\
\text { Stored Waste } \\
\left(\mathrm{m}^{3}\right)\end{array}$ & $\begin{array}{l}\text { Direct to } \\
\text { WIPP } \\
\left(\mathrm{m}^{3}\right)\end{array}$ & $\begin{array}{l}\text { to INEL for } \\
\text { treatment } \\
\left(\mathrm{m}^{3}\right)\end{array}$ & $\begin{array}{l}\text { Total to } \\
\text { WIPP } \\
\left(\mathrm{m}^{3}\right)\end{array}$ & $\begin{array}{c}\text { INEL } \\
\text { Model } 945 \\
\text { (SK) }\end{array}$ & $\begin{array}{l}\text { Mixed Waste } \\
\text { FFCA Total } \\
\left(\mathrm{m}^{3}\right)\end{array}$ & $\begin{array}{l}\text { FFCA Projected } \\
\text { Facilities Total } \\
\text { (SK) }\end{array}$ \\
\hline ANL -E & 29.1 & 7.3 & 7.3 & & & 2.7 & $\$ 501$ \\
\hline ETEC & 1.9 & 0.5 & 0.5 & & & .2 & 0 \\
\hline HANFORD & $15,608.9$ & $3,902.2$ & $3,902.2$ & & & 676.3 & 970,928 \\
\hline LBL & 0.9 & 0.2 & 0.2 & & & 3.2 & 214 \\
\hline LLNL & 235.0 & 58.8 & 58.8 & & & $2,037.2$ & 77,904 \\
\hline LANL & $10,810.9$ & $2,702.7$ & $2,702.7$ & & & $3,871.1$ & 58,448 \\
\hline MOUND & 11.9 & 3.0 & 3.0 & & & 36.5 & 2.791 \\
\hline NTS & 607.1 & 151.8 & 151.8 & & & 612.0 & 3,236 \\
\hline ORNL & $2,015.2$ & 503.8 & 503.8 & & & $1,499.5$ & $1,073,563$ \\
\hline PAD & 4.3 & 1.1 & 1.1 & & & 0.0 & 0 \\
\hline RFP & $1,040.0$ & 260.0 & 260.0 & & & $22,452.6$ & 493,653 \\
\hline SNLA & 0.9 & 0.2 & 0.2 & & & 0.0 & 0 \\
\hline SRS & $8,925.9$ & $2,231.5$ & $2,231.5$ & & & $8,242.1$ & $1,111,820$ \\
\hline WVDP & 49.1 & 12.3 & 12.3 & & & .1 & 0 \\
\hline PANTEX & 0.6 & 0.2 & 0.2 & & & 211.9 & 60,628 \\
\hline $\mathrm{U}$ of $\mathrm{Mo}$ & 0.1 & 0.0 & 0.0 & & & 0.0 & 0 \\
\hline DSSI & & & & & & 160.6 & 5,393 \\
\hline SEG & & & & & & 0.1 & $\cdot$ \\
\hline TBD & & & & & & 605.4 & 1.537 \\
\hline WIPP & & & & & & $39,427.6$ & 1,614 \\
\hline INEL & $64,774.0$ & 0.0 & $64,774.0$ & & $\$ 926,000$ & $65,220.3$ & $1,071,717$ \\
\hline $\begin{array}{l}\text { Non-INEL } \\
\text { Transportation }\end{array}$ & & & & & $\$ 68,000$ & & \\
\hline TOTAL & $104,115.8$ & $9,835.5$ & $74,609.5$ & $84,445.0$ & $\$ 994,000$ & $145,059.2$ & $\$ 4,933,947$ \\
\hline
\end{tabular}




\section{EXTERNAL COMMUNICATIONS AND PROJECT APPROVAL PLAN}

\begin{tabular}{|c|c|c|c|c|}
\hline Office & Individual & $\begin{array}{l}\text { Approval } \\
\text { Required }\end{array}$ & $\begin{array}{l}\text { Concurrence } \\
\text { Required }\end{array}$ & Briefing Required \\
\hline S-1 & H. O'Leary & $\mathrm{x}$ & & \\
\hline EM-1 & $\begin{array}{l}\text { T. Grumbly } \\
\text { K. Glozer }\end{array}$ & $\mathrm{X}$ & & $\mathrm{X}$ \\
\hline EM-2 & R. Guimond & & & $\mathrm{X}$ \\
\hline $\begin{array}{l}\text { EM-6 } \\
\text { EM-10 }\end{array}$ & $\begin{array}{l}\text { C. Henry } \\
\text { G. Pesyna }\end{array}$ & & $\mathrm{x}$ & $\mathrm{X}$ \\
\hline $\begin{array}{l}\text { EM-13 } \\
\text { EM-16 }\end{array}$ & $\begin{array}{l}\text { B. McCully } \\
\text { J. Greenwood }\end{array}$ & & & $\begin{array}{l}\mathrm{X} \\
\mathrm{X}\end{array}$ \\
\hline EM-20 & $\begin{array}{l}\text { R. Scott } \\
\text { R. Kaltreider }\end{array}$ & & & $\begin{array}{l}\mathrm{x} \\
\mathrm{x}\end{array}$ \\
\hline EM-30 & $\begin{array}{l}\text { J. Lytle } \\
\text { S. Cowan }\end{array}$ & & $\begin{array}{l}\mathrm{X} \\
\mathrm{X}\end{array}$ & \\
\hline EM-34 & M. Frei & & & $\mathrm{X}$ \\
\hline EM-351 & $\begin{array}{l}\text { P. Bubar } \\
\text { L. Wade } \\
\text { J. Rhoderick } \\
\text { (PEIS) }\end{array}$ & & & $\begin{array}{l}\mathrm{X} \\
\mathrm{X} \\
\mathrm{X}\end{array}$ \\
\hline EM-40 & $\begin{array}{l}\text { J. Owendoff } \\
\text { C. Bauer }\end{array}$ & & & $\begin{array}{l}\mathrm{X} \\
\mathrm{X}\end{array}$ \\
\hline EM-50 & C. Frank & & & $\mathrm{x}$ \\
\hline EM-60 & L. Weiner & & & $\mathrm{X}$ \\
\hline FM-1 & D. Pearman & & & $\mathrm{x}$ \\
\hline EH-1 & $\begin{array}{l}\text { T.O'Toole } \\
\text { G. Podansky } \\
\text { J. Fitzgerld }\end{array}$ & & $\mathrm{X}$ & $\begin{array}{l}\mathrm{X} \\
\mathrm{X}\end{array}$ \\
\hline $\begin{array}{l}\text { PR-1 } \\
\text { PR-13 }\end{array}$ & $\begin{array}{l}\text { R. Hopf } \\
\text { R. Cone }\end{array}$ & $\mathrm{x}$ & & $\mathrm{X}$ \\
\hline CR & J. Hubbard & $\mathrm{X}$ & & \\
\hline GC-51 & W. Dennison & & & $\mathrm{x}$ \\
\hline GC-61 & M. Egger & & & $X$ \\
\hline
\end{tabular}


EXTERNAL COMMUNICATIONS AND PROJECT APPROVAL PLAN

\begin{tabular}{|c|c|c|c|c|}
\hline Office & Individual & $\begin{array}{l}\text { Approval } \\
\text { Required }\end{array}$ & $\begin{array}{l}\text { Concurrence } \\
\text { Required }\end{array}$ & $\begin{array}{l}\text { Briefing } \\
\text { Required }\end{array}$ \\
\hline DOE-CAO & G. Dials & & & $\mathrm{X}$ \\
\hline DOE-RF & AM-EM & & & $X$ \\
\hline DOE-AL & AM-EM & & & $\mathrm{X}$ \\
\hline DOE-RL & AM-EM & & & $\mathrm{x}$ \\
\hline DOE-NV & AM-EM & & & $\mathrm{x}$ \\
\hline DOE-Oakland & AM-EM & & & $\mathrm{X}$ \\
\hline DOE-OR & AM-EM & & & $\mathrm{X}$ \\
\hline DOE-SR & AM-EM & & & $\mathrm{X}$ \\
\hline
\end{tabular}

\section{Outside Agency Briefings}

Agency

INEL Citizens

Advisory Board

OMB

National Governors

Association

Western Governors

Association

DOIT Site Implementation

Team

EPA Region 10

State of Idaho

State of Idaho

Oversight Group

\section{Individual}

T. Smith

D. Hedgepeth

P. Batt, Governor

R. Ferguson 